\title{
REPRODUCTIVE BIOLOGY OF MANGROVE PLANTS CLERODENDRUM INERME, DERRIS TRIFOLIATA, SUAEDA MARITIMA, SUAEDA MONOICA, SUAEDA NUDIFLORA
}

\author{
Jacob Solomon Raju ALURI *, Rajendra KUMAR ** and Prasada Rao CHAPPIDI *** \\ * Andhra University, Department of Environmental Sciences, Visakhapatnam, India, IN-530003, \\ ajsraju@yahoo.com \\ ** Ministry of Environment, Forest and Climate Change, Indira Paryavaran Bhavan, Jorbagh Road, \\ New Delhi, India, IN-110003, kumar.rajendra@gov.in \\ *** Andhra University, Department of Botany, Visakhapatnam, India, IN-530003, \\ prasadachram@gmail.com
}

KEYWORDS: Mangrove, entomophily, anemophily.

\section{ABSTRACT}

Floral biology, sexual system, breeding system, pollinators, fruiting and seed dispersal aspects of five mangrove associate species, namely, Clerodendrum inerme, Derris trifoliata, Suaeda maritima, S. monoica, and S. nudiflora were studied. All these species are hermaphroditic, self-compatible, and exhibit mixed breeding systems adapted for pollination by external agents. $C$. inerme and $D$. trifoliata are principally entomophilous, while Suaeda species are ambophilous. The study suggests that these plant species are important constituents of mangrove forests. $C$. inerme and $D$. trifoliata are useful in stabilizing the banks of back water creeks, while Suaeda species are useful to carpet the saline areas and desalinate the soils which are subsequently useful for agricultural activities.

ZUSAMMENFASSUNG: Fortpflanzungsbiologie der Mangrovenpflanzen Clerodendrum inerme, Derris trifoliata, Suaeda maritima, Suaeda monoica, Suaeda nudiflora.

Die Arbeit stellt Untersuchungen zu Blütenbiologie Sexual- un Fortpflanzungssystem, Bestäubern, Fruchtbildung sowie Aspekte der Samenverbreitung von fünf zu den Mangroven gehörenden Arten vor, und zwar Clerodendrum inerme, Derris trifoliata, Suaeda maritima, $S$. monoica und S. nudiflora. Alle diese Arten sind hermaphroditisch, selbstverträglich und weisen gemischte Fortpflanzungssysteme auf, die an die Fremdbestäubung angepasst sind. Clerodendron inerme und Derri trifoliata sind hauptsächlich entomophil, während die Suaeda Arten ambophil sind. Die Studie weist darauf hin, dass diese Pflanzenarten wichtige Komponenten des Mangrovenwaldes darstellen. C. inerme und D. trifoliata sind für die Uferbefestigung von Gezeitenästuaren von Bedeutung, während sich Suaeda-Arten in der Bedeckung von Salzflächen als nützlich erweisen und Böden entsalzen, die in der Folge für landwirtschaftliche Tätigkeiten von Nutzen sind.

REZUMAT: Biologia reproductivă a plantelor de mangrove Clerodendrum inerme, Derris trifoliata, Suaeda maritima, S. monoica, S. nudiflora.

Articolul prezintă studiul asupra biologiei florale, sistemului sexual, sistemului de creștere, polenizatorilor, rodirii și răspândirii semințelor la cinci specii de mangrove asociate, Clerodendrum inerme, Derris trifoliata, Suaeda maritima, S. monoica și S. nudiflora. Toate aceste specii sunt hermafrodite, auto compatibile și prezintă sisteme de creștere mixte adaptate pentru polenizare de către agenții externi. $C$. inerme și $D$. trifoliata sunt în principal entomofile în timp ce speciile Suaeda sunt ambophilous. Studiul sugerează că aceste specii de plante sunt constituenți importanți ai pădurilor de mangrove. C. inerme și $D$. trifoliata sunt utile în stabilizarea malurilor cursurilor de apă, în timp ce speciile Suaeda sunt utile pentru covorul zonelor saline și desalinizarea solurilor care sunt ulterior utile pentru activități agricole. 


\section{INTRODUCTION}

Mangrove conservation has received an increased importance in the recent past as research has increased the understanding of the values, functions, and attributes of mangrove ecosystems and the role they play in providing important ecological services and livelihoods for the mangrove associated communities. Mangrove forests are among one of the world's most productive tropical ecosystems. They are now one of the most threatened ecosystems in the world due to natural and demographic pressures (Roy and Krishnan, 2005). The mangrove vegetation is comprised of unique plant communities consisting of evergreen trees and shrubs belonging to several unrelated families growing in tropical and subtropical intertidal regions where there is constant intertidal exchange of sea water and freshwater (Spalding et al., 1997).

The focus of research on the reproductive biology of mangrove plants has almost exclusively been on the fruit and seed or seedling dispersal stage. Surprisingly, less is known about floral biology, pollination, and breeding systems, although knowledge of the effectiveness of floral mechanics and genetic isolating mechanisms is an important prerequisite to the study of successful dispersal and establishment (Primack et al., 1981; Tomlinson, 1986; Juncosa and Tomlinson, 1987; Clarke and Meyerscough, 1991; Azuma et al., 2002; Ge et al., 2003; Chiou-Rong et al., 2005; Coupland et al., 2006). In India, a few studies provide some preliminary accounts of floral biology and pollination in some mangrove plants (Solomon Raju, 1990; Solomon Raju et al., 1994; Subba Reddi and Solomon Raju, 1997; Solomon Raju et al., 2006; Solomon Raju and Jonathan, 2008; Jonathan and Solomon Raju, 2009; Pandit and Choudhury, 2001; Jonathan, 2009; Rama Mohan, 2009). The available information relates to viviparous and crypto-viviparous species, but not non-viviparous true mangroves or mangrove associate species.

This study provides information on the ecological aspects of sexual reproduction of Clerodendrum inerme (L.) Gaertn. (Verbenaceae), Derris trifoliata Lour. (Fabaceae), Suaeda maritima (L.) Dum., S. monoica Forsk. Ex. J. F. Gmel. and S. nudiflora (Willd.) Moq. (Chenopodiaceae) in Godavari-Coringa mangrove forest in India. Floral biology, sexual system, breeding system, floral rewards, pollinators, and foraging behaviour have been studied. Further, fruit and seed dispersal aspects have also been studied to the extent possible.

\section{MATERIAL, METHODS AND STUDY AREA}

The mangrove forests in Andhra Pradesh are located in the estuaries of the Godavari and the Krishna rivers. They are also found in small patches or lesser known estuaries along the coast of Visakhapatnam, West Godavari, Guntur and Prakasam districts. The present study was conducted in the Godavari Coringa mangrove wetlands. The Godavari mangrove forest is the second largest mangrove area on India's East Coast; the first largest being the Sundarbans Mangrove Forest situated in the State of West Bengal which is a part of India.

The Godavari mangrove wetland $\left(16^{\circ} 30^{\prime}-17^{\circ} 00^{\prime} \mathrm{N}\right.$ and $\left.82^{\circ} 10^{\prime}-80^{\circ} 23^{\prime} \mathrm{E}\right)$ is located in the delta of the river Godavari which is $1,330 \mathrm{~km}$ long and the second longest river in India. It branches into Vasishta and Gautami near Dowleswaram, which is considered the head of the delta. Two distributaries, Coringa and Gaderu branching-off the northern bank of the rivers Gautami and Godavari, supply freshwater to the Coringa mangroves. Freshwater flows into the mangrove wetlands of the Godavari delta for a period of six months and peak flow normally occurs from July to September, coinciding with the southwest monsoon season. During this period the entire delta, including the mangrove wetland, is submerged under freshwater since penetration of sea water is completely blocked by the large amount of incoming freshwater. Brackish water condition prevails from October to February and sea water dominates the entire mangrove wetland from March to May due to absence of freshwater discharge. 
The total area of the forest is $188 \mathrm{~km}^{2}$ (State of Forest Report, 2003, by Forest Survey of India, Dehradun, Government of India) and it is divided into nine Reserve Forests Corangi, Corangi Extension, Bhairavapalem, Rathikalava, Masanitippa, Matlatippa, Balusutippa, Kothapalem, and Kandikuppa. Of these, the first three Reserve Forests make up The Coringa Wildlife Sanctuary while the remaining Reserve Forests are situated on the southern side of Nilarevu River and fall under non-sanctuary area. The mangroves of the Coringa Wildlife Sanctuary receive tidal flushes through the Matlapalem Canal, Corangi River, and the Gaderu River; the last two rivers are the distributaries of the river Godavari. Most of the mangroves in the Coringa Sanctuary are not directly connected to the bay of Bengal. There are 36 mangrove plant species in 21 families present in this estuarine area. They include Acanthus ilicifolius (Acanthaceae), Sesuvium portulacastrum (Aizoaceae), Sarcolobus carinatus (Asclepiadaceae), Avicennia alba, A. marina, A. officinalis (Avicenniaceae), Caesalpinia crista (Caesalpiniaceae), Salicornia brachiata, Suaeda maritima, S. monoica, S. nudiflora (Chenopodiaceae), Lumnitzera racemosa (Combretaceae), Ipomoea pes-caprae, I. tuba (Convolvulaceae), Fimbristylis ferruginea (Cyperaceae), Excoecaria agallocha (Euphorbiaceae), Derris spinosa, D. trifoliata (Fabaceae), Hisbiscus tiliaeceus, Thespesia populnoidea, Malachra capitata (Malvaceae), Xylocarpus moluccensis (Meliaceae), Aegiceras corniculatum (Myrsinaceae), Aleuropus lagopoides, Myriostachia wightiana, Porteresia coarctata (Poaceae), Scyphiphora hydrophyllacea (Rubiaceae), Bruguiera cylindrica, B. gymnorrhiza, Ceriops decandra, Rhizophora apiculata, R. mucronata (Rhizophoraceae), Sonneratia apetala, S. alba (Sonneratiaceae), Brownlowia tersa (Tiliaceae), Tamarix troupii (Tamariaceae), and Clerodendron inerme (Verbenaceae). In this area, only the Coringa Wildlife Sanctuary is rich in species diversity and represents healthy mangroves.

The Coringa mangrove forest region falls under the category of "tropical humid climate" with the monsoon season commencing from June and extending up to December. The rainfall here is influenced by Southwest and Northeast monsoons. Major quantities of rainfall is contributed by the Southwest monsoon (June-September) followed by Northeast monsoon (October-December). The winter and summer months also contribute a small percentage of rainfall. During this period, the salinity is very low $(<5 \mathrm{ppt})$. From January the weather is mainly dry and progresses, gradually, to the hot summer months of March to May. The average maximum and minimum temperatures recorded are 32.36 and $24.4^{\circ} \mathrm{C}$.

\section{STUDIED MANGROVE PLANT SPECIES}

Five mangrove associate species, Clerodendrum inerme (L.) Gaertn. (Verbenaceae), Derris trifoliata Lour. (Fabaceae), Suaeda maritima (L.) Dum., S. monoica Forsk. Ex. J. F. Gmel. and S. nudiflora (Willd.) Moq. (Chenopodiaceae), were selected for the present study. All five species occur in the Godavari mangrove forest. Of these, $C$. inerme grows along the creeks and towards land, it is distributed sparsely in this mangrove forest. D. trifoliata also grows along the creeks, but it does not grow towards land. It has small populations here and there in the mangrove forest. All three Suaeda species form thick mats in upper and low salt marshes in the estuarine area and towards land as well. S. maritima and S. monoica grow together successfully, while $S$. nudiflora grows mostly in areas which are not occupied by the other Suaeda species. The locals use C. inerme and D. trifoliata as a source of firewood and Suaeda species for treating certain skin diseases by external application. 


\section{Collection of data on different aspects of reproductive biology}

Field trips to the Godavari Coringa mangroves were made prior to selecting the plant species for the study. Based on this prior field experience, five mangrove associate species as noted above were selected for study. Field investigations and experiments were conducted during the period from February 2011 to June 2014. After having preliminary field knowledge on flowering seasons of the selected species, regular field studies were made to collect information and data on the reproductive aspects selected for the study. The functional events of individual flowers, sexual status, floral rewards and their details, breeding system, flower visitors and their behaviour and pollination role, natural fruit and seed output rates and duration of fruit maturation, were carefully observed. Experiments were also conducted where essentially required. Seed dispersal aspects were also examined in the field, but only observations were made.

\section{Examination of flowering at inflorescence level}

Observations regarding the organization of inflorescences, the spatial positioning of flowers, and their position (terminal, axillary, etc.) on the plants were made since these features are regarded as important for foraging and effecting pollination by flower-visitors. The flower life was recorded by marking the just anthesed flowers and following them until fall off.

\section{Determination of anthesis and anther dehiscence}

Anthesis was initially recorded by observing marked mature buds in the field. Later, the observations were repeated three to four times on different days in order to provide accurate anthesis schedule for each plant species. Similarly, the mature buds were followed for recording the time of anther dehiscence. The presentation pattern of pollen was also investigated by recording how anthers dehisced and confirmed by observing the anthers under a 10x hand lens.

\section{Examination of flower morphology}

The details of flower morphology such as flower sex, shape, size, colour, odour, sepals, petals, stamens, and ovary were described. Further, the position of stamens, exposed or hidden, was described. The order of wilting or dropping off of floral parts was recorded. These details for the selected plant species were provided due to inadequate and confusing taxonomic descriptions.

\section{Flower behaviour}

Observations regarding the position and spatial relationships of stamens and stigma in mature bud, at anthesis, and after during the flower-life with reference to self and/or crosspollination were made very carefully.

\section{Determination of pollen output}

Mature undehisced anthers were collected from plants and placed in a Petri dish. Later, each time, a single anther was taken out and placed on a clean microscope slide (75 x $25 \mathrm{~mm}$ ) and dabbed with a needle in a drop of lactophenol-aniline-blue. The anther was then observed under the microscope for pollen, if any. If pollen grains were not there, the tissue was removed from the slide. The pollen mass was drawn into a band, and the total number of pollen grains was counted under a compound microscope (40x objective, 10x eye piece). This procedure was followed for counting the number of pollen grains in each anther collected. Based on these counts, the mean number of pollen produced per anther was determined. The mean pollen output per anther was multiplied by the number of anthers in the flower to obtain the mean number of pollen grains per flower. The characteristics of pollen grains were also recorded. 


\section{Determination of Pollen-Ovule Ratio}

The pollen-ovule ratio was determined by dividing the average number of pollen grains per flower by the number of ovules per flower. The value thus obtained was taken as pollen-ovule ratio (Cruden, 1977).

\section{Examination of nectar characters}

The presence of nectar was determined by observing the mature buds and open flowers. It was also observed whether the nectar secreted was in measurable quantity. When found measurable, the volume of nectar from 10 flowers of each plant species studied was determined. Then, the average volume of nectar per flower was determined and expressed in $\mu l$. The flowers used for this purpose were bagged at mature bud stage, opened after anthesis, and the nectar was squeezed into micropipettes for measuring the volume of nectar. Nectar sugar concentration was determined using a Hand Sugar Refractometer (Erma, Japan) for $C$. inerme and $D$. trifoliata. Ten samples were used from these species to examine the range of sugar concentration in the nectar. For the analysis of sugar types, a paper chromatography method described by Harborne (1973) was followed. Nectar was placed on Whatman number one filter paper along with standard samples of glucose, fructose and sucrose. The paper was run ascendingly for 24 hours with a solvent system of n-butanol-acetone-water (4:5:1), sprayed with aniline oxalate spray reagent, and dried at $120^{\circ} \mathrm{C}$ in an electric oven for 20 minutes for the development of spots from the nectar and the standard sugars. Then, the sugar types present, and also the most dominant sugar type, were recorded based on the area and colour intensity of the spot. The sugar content/flower is expressed as the product of nectar volume and sugar concentration per unit volume, $\mathrm{mg} / \mathrm{\mu l}$. This is done by first noting the conversion value for the recorded sugar concentration on the refractometer scale, and then by multiplying it with the volume of nectar/flower. Table 5.6 given in Dafni et al. (2005) was followed for recording the conversion value to mg of sugars present in one $\mu \mathrm{l}$ of nectar. The protocols given in Sadasivam and Manickam (1997) were followed for the quantitative estimation of sucrose, glucose, and fructose in mg/flower. Dinitrosalicylic acid method was followed for the first two sugar types while Resorcinol method for the last sugar type. Nectar amino acid types were recorded as per the paper chromatography method of Baker and Baker (1973) only for C. inerme. Nectar was spotted on Whatman number one filter paper along with the standard samples of nineteen amino acids, namely, alanine, arginine, aspartic acid, cysteine, cystine, glutamic acid, glycine, histidine, isolecuine, leucine, lysine, methionine, phenylalanine, proline, serine, threonine, tryptophan, tyrosine and valine. The paper was run ascendingly in chromatography chamber for 24 hours with a solvent system of n-butanol-glacial acetic acid-water (4:1:5). The chromatogram was detected with $0.2 \%$ ninhydrin reagent and dried at $85^{\circ} \mathrm{C}$ in an electric oven for 15 minutes for the development of spots from the nectar and the standard amino acids. The developed nectar spots were compared with the spots of the standard amino acids. Then, the amino acid types were recorded.

\section{Determination of Stigma Receptivity}

The stigma receptivity was observed visually and by $\mathrm{H}_{2} \mathrm{O}_{2}$ test. In the visual method, the stigma physical state (wet/dry) and the unfolding of its lobes were considered to record the commencement of receptivity, withering of the lobes was taken as loss of receptivity. The $\mathrm{H}_{2} \mathrm{O}_{2}$ test (Dafni et al., 2005) was followed for noting the stigma receptivity period. This test is widely followed, although it does not indicate the exact location of the receptive area. In this study, the period of slow release of bubbles from the surface of stigma following the application of hydrogen peroxide was taken as stigma receptivity. 


\section{Assessment of Breeding Systems}

Breeding systems were conducted only with $C$. inerme and $D$. trifoliata. Mature flower buds of some inflorescences on different individuals were tagged and enclosed in paper bags. They were tested in the following way, and the number of flower buds used for each mode of pollination for these species was given in the concerned tables. 1 . The stigmas of flowers were pollinated with the pollen of the same flower manually by using a brush; they were bagged and followed to observe fruit set in manipulated autogamy. 2. The flowers were fine-mesh bagged without hand pollination to observe fruit set in spontaneous autogamy. 3. The emasculated flowers were hand-pollinated with the pollen of a different flower on the same plant. They were bagged and followed for fruit set in geitonogamy. 4. The emasculated flowers were pollinated with the pollen of a different individual plant. They were bagged and followed for fruit set in xenogamy.

All these categories of flower pollinations were followed for fruit set. If fruit set was there, the percentage of fruit set was calculated for each mode.

\section{Determination of Natural Fruit Set}

The flowers/inflorescences were tagged on different plant species prior to anthesis and followed for fruit and seed set rate in open-pollinations. The number of flowers used for each plant species was different and mentioned in the concerned tables for $C$. inerme and $D$. trifoliata. In case of the Suaeda species, 50 inflorescences of ten different individuals consisting of 3,239 to 4,259 flowers were tagged and followed for fruit set. Fruit maturation period, fruit dehiscence and seed dispersal were observed in detail.

\section{Observations of Flower-Visitors}

After making preliminary observations on the categories of flower visitors, a thorough knowledge of the local insect species was obtained by observing the representative species of insects available with the Pollination Ecology Laboratory in the Department of Environmental Sciences, Andhra University, Visakhapatnam. Some insect species were identified to genus level only and a few insect species could not be identified at all, even by the Insect Taxonomic Group with the Division of Entomology, Indian Agricultural Research Institute, New Delhi. With the knowledge of local insect species, attempts were made to observe flower visitors on each plant species chosen for the study. The insect species were observed visually and by using binoculars. The insect species that could not be identified on spot were captured and later identified with the help of the identified specimens available in the Department. The hourly foraging visits of each insect species on each plant species were recorded on three or four occasions, depending on the possibility, and the data was tabulated to use the same for further analysis. For each species, 15-20 inflorescences were selected to record the foraging visits of insects. The data obtained was used to calculate the percentage of foraging visits made by each insect species per day, and also to calculate the percentage of foraging visits of each category of insects per day, to find the importance of each insect species or category of insects.

\section{Determination of pollen carryover efficiency of insects}

The flower visitors were captured during 10.00 to 12.00 each plant species and were brought to the laboratory. For each insect species, ten specimens were captured and each specimen was washed first in ethyl alcohol and the contents stained with aniline-blue on a glass slide and observed under microscope to count the number of pollen grains present. In case of pollen collecting insects, the pollen loads on their corbiculae were separated prior to washing them. From this, the average number of pollen grains carried by each insect species was calculated to know the pollen carryover efficiency of different insect species. 


\section{Determination of Foraging Behaviour of Insects}

The foraging activity of insect species was confined to daytime only, but in case of $C$. inerme, one hawk moth visited during dawn and dusk hours. The insects were observed on a number of occasions on each plant species for their foraging behaviour such as mode of approach, landing, probing behaviour, the type of forage they collect, contact with essential organs to result in pollination, inter-plant foraging activity in terms of cross-pollination, etc. Observations were also made on bud, flower, and fruit feeding activity by insects.

\section{Photography}

Study area, habitat, plant, flower and fruit details together with insect foraging activity on the flowers of the studied plant species were photographed with Nikon D40X Digital SLR (10.1 pixel) and TZ240 Stereo Zoom Microscope with SP-350 Olympus Digital Camera (8.1 pixel). Olympus Binoculars (PX35 DPSR Model) were also used to make field observations. Magnus Compound Microscope - 5x, 10x, 40x and 100x magnification was used for studying the pollen characteristics.

\section{RESULTS \\ Clerodendrum inerme (L.) Gaertn. (Verbenaceae) \\ Phenology}

It is an evergreen sprawling perennial shrub of mangrove margins that grows to a height of up to two m. It sheds leaves continually, but leaf shedding is prominent during the dry season and exhibits profuse leaf flushing during rainy season. The flowering occurs during August-October with profuse flowering during September. The inflorescence is characteristically a three-flowered cyme borne in axillary position and all the three flowers have a common base point. Individual cymes produce all three flowers either on the same day, or within two-three days. The production of flowers within cymes is dependent on the developmental stage of individual flowers. Usually, the central flower emerges first, followed by the lateral flowers. The flowers orient completely or partly erect.

\section{Flower Morphology}

The flowers are pedicellate, large (35 to $40 \mathrm{~mm}$ ), fragrant, zygomorphic and bisexual. Calyx is green, gamosepalous consisting of five sepals, cup-shaped, eight $\mathrm{mm}$ long, three-four $\mathrm{mm}$ wide and valvate at the tip. Corolla is white, tubate (30 mm long), four-five lobed at the tip; each lobe 10-12 mm long and four-five mm wide, and reflexed. The ratio of four and five petal lobes is 1:21. On the inner surface, the corolla tube is covered with short fine hairs up to the point of attachment of staminal filaments. The stamens are four or five, epipetalous, exserted, extend up to $30 \mathrm{~mm}$ from the corolla mouth when the flowers first open. The included part of the filaments is white while the excluded part of the filaments is purple. The ratio of five-stamened and four-stamened flowers is 1:12. There is a great variation in the length of stamens despite their common point of origin on the corolla tube. In case of fourstamened flowers, two long and two short or all are equal in length while in case of fivestamened flowers, two long and three short in length. The anthers have versatile fixation, are dark-coloured, dithecous and introrse. The ovary has two carpels but it is tetra-locular due to formation of a false septum. The ovules vary in number from two to four but fur-ovuled flowers are most common. They are erect, anatropous, and arranged on axile placentation. The total length of style is $45 \mathrm{~mm}$ in just opened flowers and $56 \mathrm{~mm}$ in the 2nd and 3rd day flowers. The included part of the style length is $30-33 \mathrm{~mm}$ while the excluded part of the style length is $15-18 \mathrm{~mm}$ in just open flowers. In case of 2nd and 3rd day flowers, the excluded style part is of 25-28 mm. The style ends with bifid stigma. 


\section{Floral Biology}

The mature buds with coiled stamens inside open at from 15.00 to 18.00 afternoon by the splitting of petal lobes. Petals expand and reflex immediately, then the stamens, style, and stigma extend beyond the rim of the corolla tube. The pattern of stamens and style positions is different and is distinguished into three forms. In the first form of flowers, the stamens and style are elongated and in proximity to each other soon after anthesis which facilitates contact with each other. In the second form of flowers, the stamens and style are splayed. In the third form of flowers, the stamens are fully extended, but the style is curved away from them. The style in some flowers moves away to the left side, while in some others, to the right side. Later, the stamens curl inward and style is left elongated. These three forms occur even within the cyme. These three forms occur almost in equal numbers at plant level. The anthers dehisce one hour after anthesis by longitudinal slits exposing the golden yellow pollen. All the stamens in both four-stamened and five-stamened flowers are fertile and produce almost the same number of pollen grains. The pollen output per anther is $796 \pm 51.2$. The total pollen productivity in individual four-stamened flowers is 3,184 and in five-stamened flowers is 3,980. The pollen grains are tricolporate, prolate, ectocolpus long narrow with acute ends, reticulate-rugulate with spinules widely distributed and $66.4 \pm 1.32 \mu \mathrm{m}$ long and $52.2 \pm 0.8 \mu \mathrm{m}$ wide. The stigma with forked lobes is not receptive at, and after anthesis, but it is receptive with divergent lobes on the 2nd and 3rd day. Nectar is secreted during post-anthesis period. Its secretion is gradual from anthesis onwards, but its volume is measurable on the 2nd and 3rd day. A flower produces $3.5 \pm 1.2 \mu \mathrm{l}$ of nectar which is secreted around the ovary and well protected due to the tubular nature of the corolla. The nectar sugar concentration is $13-21 \%$ and the common sugars include sucrose, glucose and fructose. The total sugar content in the nectar of a flower is $0.37 \pm 0.06 \mathrm{mg}$ (Range 0.24-0.46). The nectar amino acids include the essential amino acids such as isoleucine, valine, lysine, methionine and threonine, and non-essential amino acids such as alanine, butyric acid, glutamic acid, hydroxyl-proline, serine and aspartic acid. The corolla, together with stamens and stigma, falls off after three days. The calyx is persistent, gradually bulges, and encloses the fruit in case of fertilized flowers. The entire flower, together with pedicel, falls off if it is not pollinated or fertilized.

\section{Breeding Systems}

The results of breeding systems indicate that the flowers are self-compatible and selfpollinating. The fruit set is absent in autonomous and facilitated autogamy, $30 \%$ in geitonogamy, 83\% in xenogamy and 38\% in open pollinations (Tab. 1).

Table 1: Results of breeding experiments on Clerodendrum inerme.

\begin{tabular}{|l|c|c|c|}
\hline \multicolumn{1}{|c|}{$\begin{array}{c}\text { Mode } \\
\text { of pollination }\end{array}$} & $\begin{array}{c}\text { Number of flowers } \\
\text { pollinated }\end{array}$ & $\begin{array}{c}\text { Number of flowers } \\
\text { set fruit }\end{array}$ & $\begin{array}{c}\text { Fruit } \\
\text { set (\%) }\end{array}$ \\
\hline $\begin{array}{l}\text { Autonomous } \\
\text { autogamy } \\
\text { (bagged) }\end{array}$ & 30 & 0 & 0 \\
\hline $\begin{array}{l}\text { Facilitated } \\
\text { autogamy } \\
\text { (hand-pollinated } \\
\text { and bagged) }\end{array}$ & 25 & 0 & 0 \\
\hline Geitonogamy & 30 & 9 & 30 \\
\hline Xenogamy & 30 & 25 & 83 \\
\hline Open-pollination & 70 & 27 & 38 \\
\hline
\end{tabular}




\section{Foraging Activity and Pollination}

The flowers are specialized and the stamens and stigma are exposed when the petals unfold and reflex. The hawk moth, Macroglossum gyrans, was the first visitor to the flowers. It began its nectar-foraging activity as soon as the flowers opened during late evening and dusk hours. Again, this moth foraged during dawn hours from 05.00-07.00 h. It did not forage at other times of the day. The bees (Xylocopa pubescens and Anthophora bicincta) and butterflies (Pareronia valeria, Danaus genutia and Borbo cinnara) foraged during day time from 08.00 to $17.00 \mathrm{~h}$, but the bees showed more activity during 08.00-12.00 h while butterflies during 08.00-11.00 h (Tab. 2). However, the overall foraging activity of these daytime foragers was not very intense, and their foraging visits were not very frequent. Of the total foraging visits of these insects, M. gyrans made $39 \%$, butterflies $38 \%$, and bees $23 \%$ of visits. The body washings of these foragers collected from the flowers, revealed the presence of pollen in different numbers depending on the frequency of foraging visits, extent and certainty of contact between the stamens and stigma, and the wings and the abdomen of the foragers (Tab. 3). M. gyrans was anmefficient carrier of pollen and were also consistent foragers with great intensity towards the flowers during the entire period of flowering. The daytime foragers were not efficient carriers of pollen, not very frequent foragers, and also not consistent ones.

Table 2: List of insect foragers on Clerodendrum inerme.

\begin{tabular}{|c|c|c|c|c|c|}
\hline Order & Family & Genus & Species & $\begin{array}{l}\text { Common } \\
\text { name }\end{array}$ & $\begin{array}{l}\text { Forage } \\
\text { sought }\end{array}$ \\
\hline \multirow[t]{2}{*}{ Hymenoptera } & Apidae & Xylocopa & pubescens L. & $\begin{array}{l}\text { Large } \\
\text { Carpenter } \\
\text { Bee }\end{array}$ & $\begin{array}{l}\text { Pollen } \quad+ \\
\text { Nectar }\end{array}$ \\
\hline & Anthophoridae & Anthophora & bicincta $\mathrm{F}$. & $\begin{array}{l}\text { Blue Banded } \\
\text { Bee }\end{array}$ & $\begin{array}{l}\text { Pollen + } \\
\text { Nectar }\end{array}$ \\
\hline \multirow[t]{4}{*}{ Lepidoptera } & Pieridae & Pareronia & valeria Cr. & $\begin{array}{l}\text { Common } \\
\text { Wanderer }\end{array}$ & Nectar \\
\hline & Nymphalidae & Danaus & genutia $\mathrm{Cr}$. & Striped Tiger & Nectar \\
\hline & Hesperiidae & Borbo & $\begin{array}{l}\text { cinnara } \\
\text { Wallace }\end{array}$ & Rice Swift & Nectar \\
\hline & Sphingidae & Macroglossum & $\begin{array}{l}\text { gyrans } \\
\text { Walker }\end{array}$ & $\begin{array}{l}\text { Diurnal } \\
\text { hawk moth }\end{array}$ & Nectar \\
\hline
\end{tabular}

M. gyrans was a very swift flier and spun around the flowers in quick succession collecting nectar from a number of flowers on the same plant. It also made inter-plant movements frequently for nectar collection from the fresh, as well as, 2nd and 3rd day flowers. This moth, with $32.5 \mathrm{~mm}$ long proboscis, was very successful in reaching the nectar location at the corolla base. While approaching the flower and collecting nectar from the flowers, it always contacted the stamens and stigma of the same or different flowers with its wings and abdomen and this foraging behavior ended up in pollination. The just open flowers available during dusk hours with little nectar volume was considered to be driving the moth to make multiple visits to these flowers as well as 2nd and 3rd day flowers in which nectar is richly available, on the same and different plants. Such a foraging behaviour was considered to be increasing opportunities for cross-pollination. 
Table 3: Pollen recorded in the body washings of insects on Clerodendrum inerme.

\begin{tabular}{|l|c|c|c|c|}
\hline \multirow{2}{*}{ Insect species } & Sample size (N) & \multicolumn{3}{|c|}{ Number of pollen grains } \\
\cline { 2 - 5 } \cline { 5 - 5 } & & Range & Mean & S.D. \\
\hline Xylocopa pubescens & 10 & $13-48$ & 30.3 & 10.70 \\
\hline Anthophora bicincta & 10 & $54-126$ & 85.3 & 22.87 \\
\hline Pareronia valeria & 10 & $21-56$ & 38.1 & 11.63 \\
\hline Danaus genutia & 10 & $14-73$ & 35.9 & 16.12 \\
\hline Borbo cinnara & 10 & $11-21$ & 13.6 & 2.4 \\
\hline Macroglossum gyrans & 10 & $131-214$ & 179.1 & 32.5 \\
\hline
\end{tabular}

Among bees, $X$. pubescens was an exclusive nectar forager and A. bicincta was both a pollen and nectar forager. The two bee species robbed nectar by biting holes through the corolla tube and bypassing the floral sex organs. $X$. pubescens made a hole at the mid-part of the corolla tube to collect nectar; the exact point where the hole was made was mostly at the origin point of the epipetalous stamens covered with short hairs. The flower hung downwards when this bee species with its heavy body weight landed on the corolla tube. Then, the nectar flowed freely through the grooves present on the inside of the corolla tube from the flower base to this fixed position of stamens. The short hairs present at the fixed point of stamens prevent the flow of nectar beyond this point towards the mouth of the corolla tube. On the contrary, A. bicincta made a hole through the corolla tube at the flower base and robbed nectar by bypassing the floral sex organs. The flower did not hang downwards when this bee species with light body weight landed, and this was considered to be the reason for the bee to move to the corolla base to rob the nectar. The nectar-robbing by these two bee species did not contribute to effecting pollination. However, these bees with vibrating wings in flight mode, contacted the stamens and stigma occasionally while approaching the flowers. Such individual bees captured pollen on their wings and underside of the abdomen, and these could be effecting pollination. Further, A. bicincta also collected pollen from individual anthers.

Among butterflies, the foraging visits of $P$. valeria and $D$. genutia were relatively frequent when compared to those of B. cinnara. In P. valeria, the body length is $25.6 \mathrm{~mm}$ and the proboscis length is $29.5 \mathrm{~mm}$. In $D$. genutia, the body length is $23.9 \mathrm{~mm}$ and the proboscis length is $12.2 \mathrm{~mm}$. In $B$. cinnara, the body length is $14.1 \mathrm{~mm}$ and the proboscis length is $17.5 \mathrm{~mm}$. In P. valeria and $D$. genutia, their body length was found to facilitate them having contact between the stamens and stigma in flight mode, and while approaching the flowers. Such approaching behaviour could make the butterflies capture pollen onto their wings as well as underside of the abdomen, and eventually effect pollination. Such contacts were found to be related to the path and position the butterflies take to access the flowers. In B. cinnara, the body length was very short and its contact with the stamens and stigma was found to be rare while approaching the flowers. All the three butterfly species probed the flowers by inserting their proboscis into the throat of the corolla tube. But, the corolla tube length, far in excess of the length of proboscis of these butterflies, did not allow the latter to collect nectar situated at the flower base. The flowers in erect or partially erect position were found to be depriving the foraging butterflies of nectar. The butterflies however, were successful in gaining access to nectar in the hanging flowers in which the nectar reaches to the mid-part of the corolla tube. Such flowers acquired this orientation due to visits to them previously by X. pubescens. 


\section{Fruiting Behaviour}

Pollinated and fertilized flowers initiate fruit development immediately and take 20-25 days to produce mature fruits. Fruit is a capsule, oval-shaped, 10-15 mm long, initially green, and black when ripe and dry. Dry fruits split or break into two to four lobes depending on the number ovules fertilized, each with thick corky wall and a nutlet. Fruit dispersal occurs during November-December. Birds such as Acridotheres tristis (Indian Myna), Corvus splendens (House Crow), Corvus macrorhynchos (Jungle Crow) and Turdoides caudatus (Common Babbler) were found to feed on the nutlets and in the process, disperse them to different places. Nut-lets germinate during rainy season soon after the first monsoon rains in June.

\section{Derris trifoliata Lour. (Fabaceae)}

\section{Phenology}

It is a deciduous woody climber with pinnate leaves, growing to a length of up to 15 $\mathrm{m}$. The stem is covered with a smooth, dark brown, corky bark with orange lenticels. Young stems are dark red, strongly ridged, and have prominent lenticels. Flowering occurs from 1st week of July to 1st week of August. It exhibits massive blooming. An individual flowers for about one-two weeks. The inflorescence is a raceme of $112 \pm$ three mm length (Range 50-160) which is borne in the axils of stems growing horizontally, along the ground. An inflorescence produces $56.03 \pm 33.19$ (Range 15-182) flowers over a period of two-three days in acropetal manner. The flowers are arranged horizontal to the inflorescence axis.

\section{Flower Morphology}

Flowers are pedicellate, small, $10 \mathrm{~mm}$ long, pinkish white, odourless, delicate, papilionaceous, bisexual, and zygomorphic. Sepals are five, slightly fused at base forming a shallow cup, two mm long, light green, and glabrous. Petals are five, one pinkish white $10 \mathrm{~mm}$ long standard petal, two light pink five mm long wing petals and two white five mm long keel petals. The standard petal is broad with a light greenish-white nectar guide at the centre and hook-like structures at the base, it is posterior in position and encloses the margins of wing petals, which in turn, overlap on the margins of keel petals. The keel petals represent a boatshaped structure in which the stamens and stigma are embedded. Stamens are 10, diadelphous with nine stamens united into one bundle, while the tenth one is free. The bundled stamens form staminal tube at the base and the filaments become free towards the apex and bear monomorphic, dithecous basifixed anthers. All the ten stamens have a common origin at the flower base, their filaments are whitish green, slender, and delicate. The bundled stamens bend inward and form a conical-shaped tube at the extreme flower base, while the tenth stamen arises separately without any bending and forms open gaps on both sides towards the staminal tube. The tenth stamen is quite opposite to the standard petal. All the ten stamens have prominent upward arching. The ovary is semi-inferior with a single carpel, having six light green and shiny ovules arranged in a linear manner on marginal placentation. It has a light green style terminated with a wet, light yellow capitate stigma; the terminal portion arches upwards and extends two mm beyond the height of the anthers.

\section{Floral Biology}

The mature buds open during 06.00-11.00 h with peak anthesis at $08.00 \mathrm{~h}$. Unfolding of the standard petal indicates flower opening. The wing and keel petals do not unfold and remain in their original position as in mature bud stage, but in tensed state. All the ten anthers dehisce by longitudinal slits in mature bud stage. The number of pollen grains per anther is $1,123.9 \pm 96.76$ (Range 1,020-1,303) and per flower is 11,239 . Pollen grains are granular, triangular, smooth exine, tricolporate at equal distance, and $41.5 \mu \mathrm{m}$ in size. The pollen-ovule 
ratio is $1,873: 1$. The pollen protein content per anther is $0.6 \mu \mathrm{g}$ and per flower is six $\mu \mathrm{g}$. The stigma attains receptivity one hour after anther dehiscence and continues until the standard petal closes back, but strong receptivity occurs during 09.00-15.00 h. Nectar secretion begins inside the staminal tube at the base an hour after anthesis. Its secretion is continuous for five hours during flower-life. The total amount of nectar produced per flower is $1.50 \pm 0.2$ (Range 1.2-1.9) $\mu \mathrm{l}$. The nectar sugars included sucrose, glucose, and fructose with the first as dominant, and sugar concentration varies from 21 to $32 \%$ ( $24.5 \pm 5.3 \%)$ through the day. The total nectar sugar content per flower is $0.43 \mathrm{mg}$. Nectar is concealed by the hook-like structures of the standard petal, which hold the basal part of wing and keel petals intact. It gets exposed through openings between adjacent filaments towards the side of standard petal when wing and keel petals are depressed by the forager. The flowers begin to close slowly from $16.00 \mathrm{~h}$ onwards and close completely at $18.00 \mathrm{~h}$. Gradual movement of the standard petal to enclose the wing and keel petals completely indicates closure of the flower. The closed flowers remain so permanently and look similar to mature buds. In pollinated flowers, the petals fall off on the third day, staminal tube after seven days, and sepals after 10 days. The ovary gradually enlarges and grows into a fruit. Unpollinated flowers fall off on the 2nd day.

\section{Breeding Systems}

Floral bud abortion is $6 \%$. The results of breeding systems indicate that the flowers are self-compatible and self-pollinating. The fruit set is $2.66 \%$ in spontaneous autogamy, $31 \%$ in insect-assisted pollination, and $28.8 \%$ in open pollination (Tab. 4). Of the fruit set in open pollination, $2 \%$ of fruits abort without reaching to maturity. Fruit set per inflorescence in open pollination is $9.52 \pm 5.72$ (Range 1-30).

Table 4: Results of breeding experiments on Derris trifoliate.

\begin{tabular}{|c|c|c|c|c|}
\hline Test & Treatment & $\begin{array}{c}\text { Pollen } \\
\text { source }\end{array}$ & $\begin{array}{c}\text { Number of } \\
\text { flowers/plants }\end{array}$ & $\begin{array}{c}\text { Fruit set } \\
\text { (\%) }\end{array}$ \\
\hline Control & Un-bagged & Open pollination & $250 / 25$ & 28.8 \\
\hline $\begin{array}{c}\text { Autonomous } \\
\text { autogamy }\end{array}$ & $\begin{array}{c}\text { Fine-mesh } \\
\text { Bagged }\end{array}$ & Within flower & $150 / 10$ & 2.66 \\
\hline $\begin{array}{c}\text { Insect-assisted } \\
\text { cross-pollination }\end{array}$ & $\begin{array}{c}\text { Un-bagged, } \\
\text { Emasculated }\end{array}$ & $\begin{array}{c}\text { Other flowers on } \\
\text { the same or } \\
\text { different plants }\end{array}$ & $200 / 25$ & 31 \\
\hline
\end{tabular}

Foraging Activity and Pollination

The flowers are specialized in that the stamens, style, and stigma are in a tensed state and concealed in keel and wing petals, even after the unfolding of standard petal. They were foraged by bees and a butterfly throughout the day from 06.00 to $17.00 \mathrm{~h}$ for pollen and/or nectar (Tab. 5). The foraging activity was mainly concentrated around noon time only. The foragers were bees such as Apis dorsata, A. cerana, A. florea, Ceratina simillima, Nomia sp., Megachile sp., Pithitis binghami, Xylocopa latipes, X. pubescens, Xylocopa sp., an unidentified bee; and the butterfly, Catopsilia pyranthe. The percentage of foraging visits varied with each forager species. Megachile and Pithitis bees made 56.2\% of total visits of foragers while the other forager species made two to $8.5 \%$ of visits. All forager species probed the flowers from the front side without any side-working. Xylocopa bees and the butterfly collected only nectar, while all other bees collected both pollen and nectar. Bees on landing, depressed wing and keel petals and reached the nectar area for nectar collection, then the stamens and stigma were released violently from the keel petals. Simultaneously, the stigma and pollen ejected explosively from the anthers stuck to the ventral side of these bees. The bees such as Apis, 
Megachile, Pithitis and Xylocopa were highly efficient in depressing keel petals to access nectar. The other bees were relatively inefficient to trip the keel petals, but they appeared to be successful mostly with previously visited flowers. To collect pollen, the bees in the same or consecutive visits, gradually turned their head away from the standard petal and moved towards the location of the anthers and stigma. In doing so, they invariably contacted the stigma, effecting pollination. With the departure of these bees, the keel and wing petals returned to their original state concealing the nectar, stamens and stigma. All the bees were found to collect forage from each flower very fast, and in quest of more forage, they quickly moved between inflorescences on the same or different individual plants, contributing to selfand cross-pollination. Further, they also carried more pollen on their ventral side and pollen collecting bees stored pollen in their pollen baskets (Tab. 6). The lone butterfly, C. pyranthe, landed on the flower and inserted its proboscis slowly into the nectar location by the side of standard petal to collect nectar. It was unable to trip the keel petals to cause pollination, but it could effect pollination in the tripped flowers which received multiple visits by bees. Its proboscis was found with an average number of $91 \pm 21.0$ pollen grains (Tab. 6). Of the foragers, Megachile and Pithitis bees were consistent foragers, while all other foragers were relatively inconsistent during the entire flowering period. Red coloured thrips were found to breed in buds; when mature buds open, they move within and between inflorescences for collecting more nectar and pollen. In some flowers, numerous thrips were found and they exhausted all the secreted nectar making it unavailable for the appropriate foragers. Thrips were found to have a little role in pollination. Thrips feeding appeared to compel the bees to pay visits to a number of flowers in order to get the required quantity of forage for them.

Table 5: List of insect foragers on Derris trifoliate.

\begin{tabular}{|l|l|l|l|l|l|}
\hline Order & Family & Genus & Species & $\begin{array}{c}\text { Common } \\
\text { name }\end{array}$ & \multicolumn{1}{|c|}{$\begin{array}{c}\text { Forage } \\
\text { sought }\end{array}$} \\
\hline Hymenoptera & Apidae & Apis & dorsata & Rock bee & Pollen + Nectar \\
\hline & & Apis & cerana & $\begin{array}{l}\text { Asiatic hive } \\
\text { bee }\end{array}$ & Pollen + Nectar \\
\hline & Apis & florea & $\begin{array}{l}\text { Dwarf honey } \\
\text { bee }\end{array}$ & Pollen + Nectar \\
\hline & Anthophoridae & Xylocopa & latipes & Carpenter bee & Nectar \\
\hline & & Xylocopa & pubescens & Carpenter bee & Nectar \\
\hline & & Xylocopa & sp. & Carpenter bee & Nectar \\
\hline & Ceratina & simillima & $\begin{array}{l}\text { Small } \\
\text { carpenter bee }\end{array}$ & Pollen + Nectar \\
\hline & & Pithitis & binghami & Green bee & Pollen + Nectar \\
\hline & Anthophora & bicincta & $\begin{array}{l}\text { Blue Banded } \\
\text { Bee }\end{array}$ & Pollen + Nectar \\
\hline & Halictidae & Nomia & sp. & - & Pollen + Nectar \\
\hline & & Megachile & sp. & $\begin{array}{l}\text { Leaf cutter } \\
\text { bee }\end{array}$ & Pollen + Nectar \\
\hline & & $\begin{array}{l}\text { Unidentified } \\
\text { Bee }\end{array}$ & - & - & Pollen + Nectar \\
\hline Lepido-ptera & Pieridae & Catopsilia & pyranthe & $\begin{array}{l}\text { Mottled } \\
\text { Emigrant }\end{array}$ & Nectar \\
\hline
\end{tabular}




\section{Fruiting Behaviour}

Pollinated and fertilized flowers initiate fruit development immediately and take about a month to produce mature fruits. Fruit is one-three seeded flat, oval, leathery, and slightly wrinkled pod. It is $30-40 \mathrm{~mm}$ long and $20 \mathrm{~mm}$ across, green at first, turning light brown when ripens. Air cavities were present between the pod and seed and these cavities assist in buoyancy when the fruit falls from the plant in water. The leathery pod breaks open exposing the seed by absorbing water. Both the pod and seeds float in water and disperse to different distances depending on tidal flow and direction. During low tide period, the forest floor is exposed and the pods/seeds, if fallen at that time, settle right at the mother plant, then pods break and seeds germinate to produce new plants.

Table 6: Pollen carrying capacity of insect foragers on Derris trifoliate.

\begin{tabular}{|l|c|c|c|}
\hline Insect species & Sample size & Range & Mean \pm S.D. \\
\hline Apis dorsata & 10 & $525-989$ & $736.1 \pm 141.4$ \\
\hline A. cerana & 10 & $306-810$ & $562.2 \pm 171.9$ \\
\hline A. florea & 10 & $329-781$ & $574.4 \pm 147.3$ \\
\hline Ceratina simillima & 10 & $124-321$ & $232.3 \pm 71.0$ \\
\hline Nomia sp. & 10 & $76-156$ & $121.3 \pm 27.4$ \\
\hline Megachile sp. & 10 & $295-864$ & $508.2 \pm 197.0$ \\
\hline Pithitis binghami & 10 & $356-835$ & $599.6 \pm 190.2$ \\
\hline Xylocopa latipes & 10 & $716-1,043$ & $888 \pm 102.7$ \\
\hline X. pubescens & 10 & $674-1,176$ & $913.1 \pm 168.3$ \\
\hline Xylocopa sp. & 10 & $560-910$ & $710.6 \pm 129.8$ \\
\hline Catopsilia pyranthe & 10 & $86-132$ & $91 \pm 21.0$ \\
\hline
\end{tabular}

Suaeda maritima (L.) Dum., Suaeda monoica Forsk. Ex J. F. Gmel. and Suaeda nudiflora (Wild.) Moq. (Chenopodiaceae)

Phenology. S. maritima, S. monoica, S. nudiflora are halophytic mangrove associates. The first two are erect glabrous annual herbs, growing to a height of up to one foot, the last one is a perennial prostrate herb growing to a height of up to $1.5 \mathrm{~m}$ tall. All the three species grow in high and low salt marshes and along tidal banks. These three species invariably show different growth responses depending on the locality; high or low salt marshes. The growth forms could be distinguished, the one which grows in low marsh locality is smaller and less branched than the other one, which grows in high marsh locality. In case of S. maritima, the plants that grow at high tide mark, without other species, grow taller with many lateral branches. S. maritima and S. monoica usually form dense communities, they are usually shiny light green in colour, and turn reddish as they age. S. nudiflora grows in more widely spaced communities in relatively semi-dry areas, tend to be grey in colour, and turn blackish as it ages. Leaves are long, sickle-shaped when young, base truncate and apex acute in S. maritima; alternately, it is crowded, linear-oblong, spathulate, flat, rounded at tip and narrowed at base in S. monoica; and linear, ovate, fleshy, terete base acute, apex sub-acute in S. nudiflora. Seeds germinate in April and new plants mature to reproductive phase in three months and flowers during July-October in $S$. maritima and $S$. monoica. In $S$. nudiflora, the flowering occurs throughout the year with concentrated flowering during July-September. Inflorescences are axillary in position and the flowers are clustered in cymes; the number of flowers at each leaf axil is 9-18 in S. maritima, five-eight in S. monoica and two-four in S. nudiflora. 
Flower Morphology. The flowers are green and erect in S. maritima and S. monoica, while them greenish-yellow and semi-erect in S. nudiflora. The flowers are bisexual. They are three $\mathrm{mm}$ long, four mm wide in S. maritima, two-three $\mathrm{mm}$ long and three mm wide in S. monoica, and one-two $\mathrm{mm}$ long and two $\mathrm{mm}$ wide in S. nudiflora. The flowers in all the three species have rosaceous perianth represented by five free equal succulent, glabrous and keeled lobes or tepals. The tepals are abaxially rounded and distally hooded at maturity. The stamens are five, free, basifixed, the anthers globose-ellipsoid, exserted, introrse, dithecal and tetra-sporangiate in all species. The staminal filaments are white and ban-shaped in S. maritima and S. monoica, while they are light yellow and cylindrical in S. nudiflora. In all the three species, the filaments are soft and glabrous, and inserted near the tepal bases. In all species, the ovary is pear-shaped, uni-locular with solitary ovule on basal placentation, one $\mathrm{mm}$ long and one $\mathrm{mm}$ wide, whitish green, succulent, and glabrous. Stigmas are sessile, filiform, hairy-papillate, and arise from a pit in the top of ovary; they are three in S. maritima and S. monoica and two in S. nudiflora.

Table 7: List of insect foragers on Suaeda maritime.

\begin{tabular}{|c|c|c|c|c|c|}
\hline Order & Family & Genus & Species & $\begin{array}{c}\text { Common } \\
\text { name }\end{array}$ & Forage sought \\
\hline \multirow[t]{2}{*}{ Hymenoptera } & Halictidae & Nomia & sp. & Alkali Bee & $\begin{array}{c}\text { Pollen }+ \\
\text { Nectar }\end{array}$ \\
\hline & & $\begin{array}{c}\text { Bee } \\
\text { (unidentified) }\end{array}$ & - & - & $\begin{array}{l}\text { Pollen }+ \\
\text { Nectar }\end{array}$ \\
\hline \multirow[t]{2}{*}{ Eumenidae } & Eumenes & petiolata $\mathrm{F}$. & Potter Wasp & Nectar & \\
\hline & Ropalidia & sp. & Paper Wasp & Nectar & \\
\hline \multirow[t]{7}{*}{ Vespidae } & Rhynchium & sp. & Potter Wasp & Nectar & \\
\hline & & $\begin{array}{c}\text { Wasp } \\
\text { (unidentified) }\end{array}$ & - & - & Nectar \\
\hline & & $\begin{array}{c}\text { Wasp } \\
\text { (unidentified) }\end{array}$ & - & - & Nectar \\
\hline & & $\begin{array}{c}\text { Wasp } \\
\text { (unidentified) }\end{array}$ & - & - & Nectar \\
\hline & Syrphidae & Helophilus & sp. & Hover Fly & Nectar \\
\hline & Sarcophagidae & Sarcophaga & sp. & Flesh Fly & Nectar \\
\hline & Formicidae & Camponotus & sp. & $\begin{array}{c}\text { Carpenter } \\
\text { Ant }\end{array}$ & Nectar \\
\hline \multirow[t]{3}{*}{ Lepidoptera } & Nymphalidae & Danaus & chrysippus L. & Plain Tiger & $\begin{array}{c}\text { Leaf/dry } \\
\text { fruited } \\
\text { inflorescences } \\
\text { sap } \\
\end{array}$ \\
\hline & & Danaus & genutia Cr. & Striped Tiger & $\begin{array}{c}\text { Leaf/dry } \\
\text { fruited } \\
\text { inflorescences } \\
\text { sap }\end{array}$ \\
\hline & Hesperiidae & Borbo & $\begin{array}{l}\text { cinnara } \\
\text { Wallace }\end{array}$ & Rice Swift & $\begin{array}{c}\text { Leaf/dry } \\
\text { fruited } \\
\text { inflorescences } \\
\text { sap }\end{array}$ \\
\hline Coleoptera & Curculionidae & Chrysochoris & sp. & Beetle & Pollen \\
\hline
\end{tabular}




\section{Floral Biology}

The flowers are open from $08.00-11.00 \mathrm{~h}$ in all the three species. In all, the papillate stigma lobes protrude out of the maturing (bulging) bud and are receptive a day before anthesis. The lobes gradually wither and become unreceptive by the time the anthers protrude out due to unfolding of the hooded perianth lobes during anthesis. The protruded stamens extend beyond the height of withered stigma lobes and dehisce by longitudinal slits exposing the bright yellow coloured and powdery pollen grains. In all the three species, the pollen grains are spheroidal, pantoporate, multiporate and vary in size. It is $25.5 \pm 0.86 \mu \mathrm{m}$ in S. maritim, $20.37 \pm 1.22 \mu \mathrm{m}$ in $S$. monoica and $18.21 \pm 0.29 \mu \mathrm{m}$ in $S$. nudiflora. The pollen output per anther is 3,818 \pm 28.34 in S. maritima, 3,253 \pm 17.34 in S. monoica and 2,035 \pm 21.23 in S. nudiflora. The pollen output per flower is 19,090 in S. maritima, 16,265 in S. monoica and 10,175 in $S$. nudiflora. The pollen-ovule ratio is equal to the pollen out per anther due to oneovuled flowers in all the three species. The flowers in all species produce $1.2 \pm 0.21 \mu \mathrm{l}$ of nectar; it is available only during staminate phase. In these species, the perianth lobes close back and cover the ovary, but not the anthers by the evening of 2nd day. The stamens fall off subsequently on 3rd or 4th day. The perianth lobes gradually bulge along with the growing seed, and hence the perianth acts as seed cover.

Table 8: Pollen recorded in the body washings of insects on Suaeda maritime.

\begin{tabular}{|l|c|c|c|c|}
\hline Insect species & $\begin{array}{c}\text { Sample size } \\
\text { (N) }\end{array}$ & \multicolumn{3}{|c|}{ Number of pollen grains } \\
\cline { 3 - 5 } & 10 & $78-206$ & 142.4 & 36.81 \\
\hline Nomia sp. & 10 & $93-227$ & 156.5 & 41.58 \\
\hline Bee (unidentified) & 10 & $25-113$ & 81.7 & 26.92 \\
\hline Eumenes petiolata & 10 & $36-75$ & 55.2 & 12.61 \\
\hline Ropalidia sp. & 10 & $45-87$ & 68.3 & 14.91 \\
\hline Rhynchium sp. & 10 & $26-74$ & 52.5 & 16.72 \\
\hline Wasp (unidentified) & 10 & $43-91$ & 64.4 & 15.53 \\
\hline Wasp (unidentified) & 10 & $16-52$ & 36.1 & 11.49 \\
\hline Wasp (unidentified) & 10 & $20-64$ & 45.3 & 12.80 \\
\hline Helophilus sp. & 10 & $24-58$ & 41.1 & 10.80 \\
\hline Sarcophaga sp. & 10 & $32-84$ & 50.7 & 16.45 \\
\hline Camponotus sp. & \multicolumn{3}{|c}{} \\
\hline
\end{tabular}

Table 9: List of insect foragers on Suaeda monoica.

\begin{tabular}{|c|c|c|c|c|c|}
\hline Order & Family & Genus & Species & $\begin{array}{c}\text { Common } \\
\text { name }\end{array}$ & $\begin{array}{c}\text { Forage } \\
\text { sought }\end{array}$ \\
\hline Hymenoptera & Apidae & Apis & dorsata F. & $\begin{array}{c}\text { Rock Honey } \\
\text { Bee }\end{array}$ & $\begin{array}{c}\text { Pollen }+ \\
\text { Nectar }\end{array}$ \\
\hline & Apis & cerana F. & $\begin{array}{c}\text { Indian Honey } \\
\text { Bee }\end{array}$ & $\begin{array}{c}\text { Pollen }+ \\
\text { Nectar }\end{array}$ \\
\hline & Apis & florea F. & $\begin{array}{c}\text { Dwarf Honey } \\
\text { Bee }\end{array}$ & $\begin{array}{c}\text { Pollen }+ \\
\text { Nectar }\end{array}$ \\
\hline & Eumenidae & Eumenes & petiolata F. & Potter Wasp & Nectar \\
\hline & Sarcophagidae & Sarcophaga & sp. & Flesh fly & Nectar \\
\hline
\end{tabular}


Table 10: Pollen recorded in the body washings of insects on Suaeda monoica.

\begin{tabular}{|l|c|l|c|r|}
\hline \multicolumn{1}{r|}{ Insect species } & Sample size & \multicolumn{3}{c|}{ Number of pollen grains } \\
\cline { 3 - 5 } & & Range & \multicolumn{3}{c|}{ Mean } & S.D. \\
\hline Apis dorsata & 10 & $128-263$ & 195.1 & 44.04 \\
\hline Apis cerana & 10 & $154-235$ & 203.3 & 28.25 \\
\hline Apis florea & 10 & $135-276$ & 219.2 & 39.55 \\
\hline Eumenes petiolata & 10 & $46-115$ & 78.3 & 19.84 \\
\hline Sarcophaga sp. & 10 & $31-73$ & 46.4 & 12.74 \\
\hline
\end{tabular}

Table 11: List of insect foragers on Suaeda nudiflora.

\begin{tabular}{|c|c|c|c|c|c|}
\hline Order & Family & Genus & Species & $\begin{array}{l}\text { Common } \\
\text { name }\end{array}$ & $\begin{array}{l}\text { Forage } \\
\text { sought }\end{array}$ \\
\hline \multirow[t]{2}{*}{ Hymenoptera } & Halictidae & Nomia & sp. & Alkali Bee & $\begin{array}{l}\text { Pollen + } \\
\text { Nectar }\end{array}$ \\
\hline & Vespidae & Rhynchium & sp. & $\begin{array}{l}\text { Black Potter } \\
\text { Wasp }\end{array}$ & Nectar \\
\hline \multirow[t]{3}{*}{ Lepidoptera } & Nymphalidae & Danaus & $\begin{array}{l}\text { chrysippus } \\
\text { L. }\end{array}$ & Plain Tiger & $\begin{array}{l}\text { Leaf/dry } \\
\text { fruited } \\
\text { inflorescenc } \\
\text { es sap }\end{array}$ \\
\hline & & Danaus & genutia $\mathrm{Cr}$. & $\begin{array}{l}\text { Striped } \\
\text { Tiger }\end{array}$ & $\begin{array}{l}\text { Leaf/dry } \\
\text { fruited } \\
\text { inflorescenc } \\
\text { es sap }\end{array}$ \\
\hline & Lycaenidae & Euchrysops & cnejus F. & Gram Blue & $\begin{array}{l}\text { Leaf/dry } \\
\text { fruited } \\
\text { inflorescenc } \\
\text { es sap }\end{array}$ \\
\hline
\end{tabular}

Table 12: Pollen recorded in the body washings of insects on Suaeda nudiflora.

\begin{tabular}{|l|c|l|c|r|}
\hline \multirow{2}{*}{ Insect species } & \multirow{2}{*}{$\begin{array}{c}\text { Sample size } \\
\text { (N) }\end{array}$} & \multicolumn{3}{c|}{ Mumber of pollen grains } \\
\cline { 3 - 5 } & 10 & $74-213$ & 142.6 & Sange \\
\hline Nomia sp. & 10 & $35-92$ & 60.9 & 15.36 \\
\hline Rhynchium sp. & & & & \\
\hline
\end{tabular}

\section{Breeding behavior}

In all the three species, the flowers are strikingly protogynous, the mature bud stage is pistillate due to the protrusion and receptivity of stigmatic lobes whilein the post-anthesis stage is staminate due to the cessation of stigma receptivity by the time of anthesis and dehiscence of anthers after anthesis. The pistillate and staminate phases are therefore temporally separated and this situation is a type of temporal dioecy. This sexual system completely prevents autonomous and facilitated autogamy, but facilitates both geitonogamy and xenogamy. Geitonogamy occurs due to pollen transfer from the pollen of staminate phase flowers to the stigmatic lobes of pistillate phase mature buds within the plant; if pollen transfer occurs between flowers of different plants within or across populations, it results in xenogamy. The 
hairy-papillate stigmatic lobes in all the three species, standing out distinctly from the mature buds, were found to be capturing pollen driven by wind. The powdery and multi-porate nature of pollen grains enable them to fly and disperse easily by wind and their dispersal is further propelled by vast uniform mats of populations of Suaeda species. The wind-driven pollen deposition on the stigmatic lobes and leaves can be seen with the naked eye, and hence, anemophily was considered to be effective. Anemophily was very effective in high salt marshes devoid of water-logged conditions. In the low salt marshes where water-logged or water-saturated conditions occur, water currents were found to carry and disperse pollen effectively; here considerable aerial parts of the plants were merged or intermittently exposed, and hence pollen was wet, making anemophily mostly ineffective. In all the three species, fruit set in open-pollinations is 93-95\% indicating the success rate of both geitonogamy and xenogamy. This high success rate could be due to the production of a single ovule in the flowers for which the deposition of a few viable pollen grains on the stigmatic lobes is sufficient.

\section{Foraging Activity and Pollination}

In all the three species, the flowers were foraged by bees, wasps, and flies during daytime from the 08.00 to $17.00 \mathrm{~h}$ with more foraging activity during the $09.00-12.00 \mathrm{~h}$, and less activity during afternoon period in high salt marshes and in low salt marshes where soil was not saturated with water (Tabs. 7, 9 and 11). The foraging activity pattern of all these categories of insects was almost similar and coincided well with the standing crop of floral rewards. S. maritima was foraged by Nomia bees and one unidentified bee for pollen and nectar; by wasps, Eumenes petiolata, Ropalidia sp., Rhynchium sp. and three unidentified wasp species; and by flies Helophilus sp. and Sarcophaga sp. for nectar only. Camponotus ants also foraged for nectar, but they were resident foragers and remained on the plants throughout the flowering season. S. monoica was foraged by honey bees, Apis dorsata, A. cerana, and A. florea for both pollen and nectar; by wasps, Eumenes petiolata, Rhynchium sp.; and by the fly, Sarcophaga sp. for nectar only. S. nudiflora was visited by Nomia bees for both pollen and nectar while Rhynchium wasps for nectar only. In all the three species, thrips were nectar and pollen feeders; they have collected most of the nectar during mature bud stage and after anthesis, and also pollen during post-anthesis stage as soon as the anthers dehisce. Further, the iridescent green tortoise beetle, Chrysochoris (Scuteleridae), collected S. maritima pollen voraciously while an unidentified immature stage of an insect was found to feed on the nectar and pollen of $S$. nudiflora. The percentage of foraging visits made each category of insects varied with each Suaeda species. In S. maritima, bees made $21 \%$, wasps $62 \%$, and flies $17 \%$ of total foraging visits. In S. monoica, bees made $54 \%$, wasps $35 \%$, and flies $11 \%$ of total foraging visits. In S. nudiflora, Nomia bee made $48 \%$ and Rhynchium wasp made $52 \%$ of total foraging visits.

In all the three plant species, the flowers with dehisced anthers representing staminate phase attracted bees due to clear-cut display of bright yellow pollen. The bees, while collecting pollen and nectar from such flowers, invariably also accidentally contacted the flowers in pistillate phase occurring in the same cluster or nearby clusters on the same flowering branch due to their close proximity to each other, and, this foraging behaviour was considered to be effecting geitonogamy. The production of a few staminate phase flowers each day at branch or plant level was found to be driving the bees to make frequent inter-plant visits within and between populations in the entire area in order to collect more nectar and pollen. They were effective carriers of pollen and their body washings revealed the presence of 142-156 pollen grains in case of S. maritima (Tab. 8), 195-219 pollen grains in case of $S$. monoica (Tab. 10), and 142 pollen grains in case of S. nudiflora (Tab. 12). Wasps, flies and ants attempted to 
collect nectar from pistillate and staminate phase flowers without any discrimination; such a foraging behaviour was considered to be facilitating both geitonogamy and xenogamy. The flowers with minute traces of nectar were found to be driving the wasps to make frequent interplant visits in order to collect more or optimal levels of nectar due to their high energy requirement. They were found to carry 36-82 pollen grains on their bodies in case of S. maritima (Tab. 8), 78 pollen grains in case of S. monoica (Tab. 10), and 61 pollen grains in case of S. nudiflora (Tab. 12) indicating their pollen carrying capacity. In case of flies, they tended to remain on the same plant for long time collecting nectar from as many flowers as possible due to their low energy requirement. Their body washings revealed the presence of an average of 41 to 45 pollen grains in case of S. maritima (Tab. 8), 46 pollen grains in case of S. monoica (Tab. 10), and hence they were also pollen carriers to some extent. Ants, as resident foragers and with low energy requirement, were considered to be important for geitonogamy if they confined to the same plant, and for xenogamy if they crawled to other nearby plants for nectar collection. They were found to carry an average of 50 pollen grains due to their nectar foraging activity. The nectar and pollen feeding activity of thrips was found to be an important driver, especially for bees and wasps to collect forage from a number of individual flowers within and between populations. Certain insects recorded were common to all the three plant species which co-exist in the same area and their alternate foraging visits could lead to the deposition of mixed pollen on each of these plant species. Such mixed pollen deposition could block the receptive area of the stigma lobes and reduce the opportunities for legitimate geitonogamous and xenogamous pollinations in each plant species.

In all the three Suaeda species, the nymphalid butterflies, Danaus genutia, D. chrysippus, the lycaenid Euchrysops cnejus, and the hesperiid, Borbo cinnara, were found to feed on the sap of leaves prior to flowering and on dry fruited branches. These butterflies mainly concentrated on S. maritima and S. monoica for sap collection. Further, they never visited the flowers for nectar collection and hence were not pollinators.

\section{Fruiting Behaviour}

In all the three species, fruit is an urticle with $1.5 \mathrm{~mm}$ wide and one mm long persistent perianth. Hooded perianth segments cover seeds over the margins. It matures within three-four weeks. Each fruit invariably produces a single seed. Seeds ripen during August-October. Seeds are brownish-black, smooth, glossy, ovoid, 1.2-1.5 mm diameter, finely punctuate near the edges and beaked. Whole plants break off easily and roll on the floor while shedding its diaspores. Fruits with seeds intact, and/or seeds shed from fruits, float on water due to their ability for buoyancy. The fruits and seeds thus disperse and settle in the entire extent of salt marshes or coastal areas.

\section{DISCUSSION}

The reproductive biology of mangrove plants displays characteristics of pioneer species such as possessing self-compatibility and utilizing a wide variety of pollinators including insects, birds, and bats. The characteristic wide distribution and long-range seed dispersal of mangrove plants may also favour a broad range of pollen vectors (Azuma et al., 2002). Mangroves are adapted to a generalized type of pollinators and thus competition for the available pollinators is reduced (Tomlinson, 1986). Since flowers are available throughout the year, at least on a few mangrove plants, pollinators are able to perform foraging activities on a regular basis (Fernandes, 1999). The capacity of mangroves to convert floral visitation to flower fertilization and fruit set is an important step in the recruitment process, and ultimately to the maintenance of existing mangrove communities (Coupland et al., 2006). 
Mangrove plants must interact, or even compete for the available pollinators, and the interaction minimizes the competition for pollinators so that the pollinator resource is used in the most efficient manner possible. In mangroves, the spectrum of pollinators is broad so that no plant is highly dependent on one specific pollinator and the plants are specialized only to the extent of being associated with a given class of pollinator. These conclusions have a reasonable explanation in the wide geographical range of mangroves, plants are not constrained by a dependence on a specific pollinating agent with a limited geographic range. Since each mangrove plant species adapts primarily to a generalized type of pollinator, competition for the available pollinator resource is reduced (Tomlinson, 1986).

Few studies have assessed how successful mangroves are at utilizing pollinators, how much reproductive effort is required to produce a single propagule, and whether propagule production is limited by resources or by pollinators. A more complete understanding of the reproductive biology of mangroves is useful for effective mangrove rehabilitation programmes (Coupland et al., 2006).

Fruit and seed characteristics in non-viviparous mangrove species, especially mangrove associates, have been little studied. Mangrove associates have been in fact largely ignored, and most of the studies conducted are related to viviparous and prominent nonviviparous species. The shrub and herb species that constitute mangrove associates have been little studied and the documented information does not provide any clue to understanding their reproductive biology with reference to their floral ecology, breeding systems, pollination syndromes, fruiting ecology, and fruit or seed dispersal. Field observations and experimental results obtained in the present study on certain aspects of reproductive ecology on Clerodendrum inerme, Derris trifoliata, Suaeda maritima, S. monoica, and S. nudiflora have been examined and interpreted in the light of the related literature available on the studied mangrove associate plant species.

\section{Clerodendrum inerme}

Mangrove species are usually categorized as "exclusive” species that are limited to the mangrove environment and "non-exclusive" species that are mainly distributed in a terrestrial or aquatic habitat but also occur in the mangrove ecosystem. These non-exclusive species are referred to as semi-mangrove, back mangrove, or mangrove associate (Lacerda et al., 2002; Parani et al., 1998; Tomlinson, 1986). In case of $C$. inerme, there is a controversy with reference to its status as a constituent of mangrove forests. Parani et al. (1998) reported that it is a fringe species found abundantly both on the landward edge as well as deep inside the mangrove environment. Saenger (2002) considered it as a mangrove, but he has not mentioned whether it is a true mangrove or a mangrove associate. Satyanarayana et al. (2002) did not consider it as a mangrove species. Wang et al. (2011) reported that $C$. inerme behaves like both a true mangrove and a mangrove associate due to its largest salinity tolerance. These different reports indicate that there is no consensus on $C$. inerme to classify it as a component of mangrove species. Nevertheless, in this study, $C$. inerme is considered to be a mangrove associate. It is a perennial shrub that occurs predominantly in the mangrove forests and along the coastlines. It is exposed to a wide range of fluctuations in salinity due to its occurrence in the landward sites as well as in the open sites within the mangrove zonations at the study area. Chethana et al. (2013) stated that it has an advantage over other species that lack strategies to deal with the salt in the soil, and thus, is an excellent competitor in saline environments. Therefore, it plays an important role in the formation and stabilization of forest floor due to its prolific growth. 
C. inerme is a rainy season bloomer. It produces typical three-flowered cymes which are quite prominent and displayed well because of its white flowers against bright green foliage. Primack et al. (1981) reported that this species produces two-eight flowers in each cyme and this report does not agree with the present study indicating that the each cyme is three-flowered. Further, these authors noted that the flowers in a cyme generally remain at the same developmental stage, so that the flowers in the same cyme are unlikely to pollinate each other. In the present study, it is found that the flowers within the cyme show different developmental stages; open, whether on the same day or over a period of three days at the most. This difference in developmental stages of flower buds is most likely to pollinate each other if pollinators are available. Further, the cymes of different branches of the same plant also show various developmental stages so that the cymes of the same plant pollinate each other through geitonogamy if there is pollinator activity.

The flowers open during morning hours in Clerodendrum infortunatum (Byragi Reddy and Subba Reddi, 1995) and during late evening hours in C. molle in which the flowers are fragrant (McMullen, 2011). In C. inerme, the flowers are fragrant and open during evening hours as in C. molle. Primack et al. (1981) also reported that the flowers are fragrant but they have not mentioned the time of flower-opening. These authors stated that the calyx cup is covered with an irregular series of raised elliptical glands which, apparently, function as extrafloral nectaries and the ants commonly feed at them. In the present study, $C$. inerme does not show such glands on the calyx cup, and also, the ants do not visit the flowers.

Yao-Wu et al. (2010) stated that an unusual pollination syndrome that prevents selfpollination exists in the genus Clerodendrum. This pollination syndrome is functional through dichogamy and herkogamy. The usual floral mechanism is that when the flower opens, the stamens stand erect, parallel to the central axis of the flower, while the style bends over holding the stigma beyond the rim of the corolla. After the pollen is shed, the stamens curl up or bend over, and the style straightens out bringing the stigma to the centre of the flower. Such a movement and function of floral sex organs precludes self-pollination. Keng (1990) reported that $C$. laevifolium is pollinated by insects such as bees and butterflies. Byragi Reddy and Subba Reddi (1995) reported that $C$. infortunatum, with morning anthesis, is exclusively pollinated by papilionoid butterflies; the pollination occurs due to striking of anthers and stigma with the wings of butterflies. Such a form of pollination is referred to as pterigotribic pollination. Meera Bai (2014) reported that the typical butterfly pollination in C. infortunatum is because of non-promiscuity of floral rewards to other foragers. She also noted that this pollination syndrome is a necessary pre-condition for the rise of floral isolating mechanism. Shamim et al. (2010) reported that $C$. viscosum is exclusively cross-pollinated by ants, butterflies, and hawk-moths. Rohitash and Jain (2010) noted that $C$. splendens is pollinated by Xylocopa, Eumenes sp. and Camponotous campestris. McMullen (2011) reported that C. molle with night/late evening anthesis is pollinated by nocturnal and diurnal visitors. Nocturnal visitors include ants, spiders, hawk moths, and roaches whereas diurnal visitors include carpenter bees and ants. Sakamoto et al. (2012) reported that $C$. trichotomum is pollinated by the carpenter bees, Xylocopa species, the butterflies, Papilio species, and the hawk moth Macroglossum. Primack et al. (1981) reported that C. inerme is never visited by daytime visitors but is visited by one large hawk moth during dusk hours.

C. inerme, with evening anthesis, white long corolla with hairy interior to exclude other insects, and strong fragrance, appear to be adaptations for hawk moth pollination (Primack et al., 1981). In the present study, it is visited and pollinated by one large hawk moth, 
Macroglossum gyrans, as soon the flowers are open during evening hours. It is a nectar feeder, but the nectar in just open flowers is almost absent. The new flowers take one to two hours to secrete nectar. In such a situation, this hawk moth is compelled to pay multiple visits to the new as well as old flowers. The flowers opened one or two days before are nectar-rich and serve as the principal nectar source for the visiting hawk moths during evening hours. Further, the same hawk moth was the first visitor to the flowers on the following day during dawn hours by which time the flowers accumulate nectar in considerable amount. The nectar is in considerable volume and sucrose-rich with a sugar concentration of $13-21 \%$. This finding is in agreement with the report of Cruden et al. (1983) that in lepidopteran-pollinated flowers, the nectar is rich in volume and sucrose-rich with the sugar concentration ranging from 15 to $25 \%$. Further, it is a source of certain essential and non-essential amino acids and protein content. In the present study, the hawk moth, being a swift flier, visits numerous flowers on the same day and different plants in quick succession in order to quench its thirst for nectar and, in effect, contributes to both self (geitonogamy) and cross-pollination. Primack et al. (1981) noted that the purple colour of the filament and style presumably make them difficult for the hawk moth to see and avoid. The versatile anthers, with pollen in grooves, allow pollen to be placed precisely on the hawk moth proboscis. In the present study, M. gyrans approaches the flowers either laterally or from the front through the stamens and stigma to insert its proboscis into the corolla tube to collect nectar. In this process, its contact with the stamens and stigma are random, but not with certainty, and also there is no precise placement of pollen from the versatile anthers on the proboscis of the moth. The pollen deposition largely occurs on the wings and abdomen. Further, the production of small quantity of pollen in individual flowers of $C$. inerme is another indication that it is adapted for nectar-feeding lepidopteran, in this case $M$. gyrans. Therefore, $M$. gyrans is the appropriate and principal pollinator of $C$. inerme.

In the present study, $C$. inerme is also visited by day-time visitors such as butterflies and bees, but their overall foraging activity is low and is also not consistent throughout the flowering period. The butterflies with their short proboscis are not capable of collecting nectar from the long tubular corolla but they are successful in collecting nectar from the flowers that were previously visited Xylocopa bees. Such flowers stay in hanging position, and the nectar is accumulated at the attachment point of staminal filaments covered by internal hairs. The butterflies access this nectar with their proboscis without any difficulty. Xylocopa bee bites a hole on the mid-part of the corolla tube where the epipetalous stamens take their origin, and which are covered by short hairs inside. When Xylocopa lands on the corolla tube, the flower hangs downward and as a result, the nectar flows to the attached point of stamens, then the bee collects nectar by biting a hole on the corolla tube. Anthophora bee also bites a hole to collect nectar, but it does at the base of the corolla tube, this is because its light weight does not bring the flower to hanging position when it lands. Therefore, the two bee species are typical nectar robbers. Both the butterflies and bees, however, contribute to sporadic pollination while approaching the flowers during which their wings and abdomen strike the anthers and style.

Nectar robbing is a behaviour exhibited by some species of bees in which nectar is obtained through holes bitten near the bases of the corolla tubes. Nectar robbers are subdivided into primary nectar robbers, which make the holes and then extract the nectar, and secondary nectar robbers, which obtain nectar by using holes made by primary robbers (Inouye, 1983). Carpenter bees are the most notorious primary nectar robbers (Barrows, 1980), they make perforations with the maxillae (Barrows, 1976) and this method is probably used by all Xylocopa bees (van der Pijl, 1954). These bees employ this method when they are unable to access nectar, such a situation exists mostly in tubular flowers (Barrows, 1980). In the present study, 
Xylocopa and Anthophora are primary nectar robbers, since they bite holes on the corolla tube of $C$. inerme. Secondary robbers of nectar are absent at the flowers of this plant species.

Nectar robbing is variously interpreted in relation to host fitness. It has positive or neutral or mutualistic effects on host fitness in terms of increase, decrease, or no effect in seed set rate (Zhang et al., 2009). The removal of floral nectar by robbers decreases the standing crop, and in some cases, changes the sugar concentration of nectar available to other pollinators (Pleasants, 1983). Longer pollinator flight distances generally translate into increased pollen flow and increased outcrossing rates (Fenster, 1991). If nectar robbers are the cause of longer flight distances by the legitimate pollinators, they could be increasing the fitness of the robbed plants by promoting outcrossing. The robbers could then be considered as mutualists. Guitian et al. (1994) observed that nectar robbing by carpenter bees had a positive effect on seed set in Pterocoptis grandiflora. Zimmerman and Cook (1985), and Castro et al. (2008, 2009) stated that nectar robbing, besides influencing host female fitness, could potentially enhance male fitness and increase the offspring outcrossing rate through forcing legitimate pollinators to fly farther in search of nectar, thus expanding the pollen dispersal distance and neighbourhood size, and reducing geitonogamy. In the present study, nectar robbing by both Xylocopa and Anthophora could potentially enhance male fitness by driving the legitimate pollinator $M$. gyrans to fly farther and farther in search of nectar. Such a foraging behaviour by this pollinator and expands the pollen dispersal distance and promotes out-crossing rate in C. inerme.

Primack et al. (1981) reported that $C$. inerme is strongly protandrous, but did not explain how it works with reference to the movements of stamens and stigma within the flower. They have also not mentioned whether there are different forms of flowers based on the position of stamens and style during the flower life. In this study, three forms of flowers have been distinguished with reference to the position of floral sex organs. The first form is characterized by elongated stamens and style which occur in close proximity to each other just after anthesis, this facilitates contact between the stamens and stigma. The second form is characterized by the scattered position of stamens and style. In the third form, the stamens are fully extended while the style is curved away from them either to the left or to the right, subsequently the stamens curl inward and the style elongates. Interestingly, the three flower forms can be found within a cyme also. Such flower forms have been reported in C. molle (McMullen, 2011). These forms of flowers appear to have evolved to prevent autonomous and facilitated selfing but certainly not geitonogamy. The strong protandry in $C$. inerme does not facilitate individual flowers from self-pollinating, but it facilitates different flowers on the same plant to pollinate each other through geitonogamy. This is further substantiated by fruit set in geitonogamous pollinations. Although geitonogamy is self-fertilization, in that the pollen fertilizing the ovules originates from the same parent plant, different parts of branches of the plant may diverge genetically through somatic mutation (Roubik, 1995). Such a genetic divergence was experimentally proved in Byrsonima crassifolia, in which one of five trees used in experiments was initially found to be self-incompatible produced fruits through selfpollination when the flowering period was nearly over, and in Pscidia carthagenensis in which one-day old artificially self-pollinated flowers did not set fruit but two-days old flowers set some fruits (Baker et al., 1983). In C. inerme, the protandry is functional, partially since fruit set occurs through geitonogamy. That the protandry functional in this species is important as an out-breeding mechanism and it is also reflected in the percentage of fruit set recorded through xenogamy. The high fruit set recorded in open-pollinations despite mechanisms which prevent self-pollination in individual flowers, strongly suggests that $C$. inerme is self- 
compatible. Geitonogamy would allow fruit set in isolated colonizing plants. Initial colonization occurs usually by a single seed floating in tidal water. As a result, certain floral mechanisms which promote out-crossing with its associated genetic advantages can be expected in established populations (Primack et al., 1981). In C. inerme, the protandry, together with different positions of stamens and style in different sets of flowers, would allow fruit set in isolated or congregated individuals while totally preventing selfing within individual flowers. Such a dual breeding system is advantageous for $C$. inerme to colonize new areas in mangrove and coastal areas, and also the nearby terrestrial habitats. The prolific growth of $C$. inerme with its extensive root system in these areas is important to control land and beach erosion, and stabilize forest floor.

Wheeler et al. (1992) noted that fruit or seed dispersal in Clerodendrum genus through birds. Keng (1990) reported in C. laevifolium that birds are probably involved in fruit or seed dispersal. Lorence and Flynn (1997) stated that C. macrostegium is spread by fruit eating birds. In $C$. inerme, the fruit is a capsule and breaks into different lobes depending on the number of nutlets produced inside. Each lobe contains a nutlet. Birds such as Acridotheres tristis (Indian Myna), Corvus splendens (House Crow), Corvus macrorhynchos (Jungle Crow), and Turdoides caudatus (Common Babbler) disperse nutlets or seeds in the study area. This event occurs during early winter season. Seed germination occurs as soon as monsoon sets in during June; seedlings grow and produce new plants.

A few stated that Clerodendrum species serve as larval hosts for lycaenid butterflies. C. laevifolium is a larval host for Zelthus amasa maximinianus (Keng, 1990), C. glabrum for Hypolycaena philippus philippus (Ivor, 1994), and C. indicum for Spindasis vulcanus (Kunte, 2007). Here, field observations show that $C$. inerme is a larval host too for S. vulcanus. Clerodendrum genus is probably the best larval host plant for lycaenid butterflies. Further studies may provide information on other butterflies that use this plant species as a larval host.

\section{Derris trifoliata}

The plant is a deciduous woody climber distributed from oligohaline to polyhaline zones in the mangroves. It displays massive flowering for about a month during rainy season. The acropetal anthesis and the flowers borne in nearly erect racemose inflorescences are quite distinct against the foliage. The floral characteristics, such as small size, pinkish white papilionaceous corolla with explosive pollen release mechanism, and zygomorphic symmetry, indicate that the plant has specialized pollination mechanism adapted for tripping by external agents. Such an explosive pollination mechanism has also been reported in the allied species, Pongamia pinnata (Solomon Raju and Rao, 2006), other Fabaceae members (Meeuse, 1961), and also in other plant families such as Lamiaceae (Solomon Raju, 1990), Loranthaceae (Feehan, 1985), Onagraceae (Plitmann et al., 1973), Rhizophoraceae (Davey, 1975; Tomlinson, et al., 1979), Marantaceae (Davis, 1987), Urticaceae (Taylor, 1942), Ericaceae (Marie-Victorin, 1942), Fumariaceae, Musaceae, Acanthaceae (Proctor and Yeo, 1972), Cornaceae (Mosquin, 1985), and Orchidaceae (Proctor and Yeo, 1972; Gottsberger, 1989).

In D. trifoliata, the forenoon anthesis and pollen and nectar as rewards, attract daytime foragers. The nectar feeding foragers require strength to depress keel petals in order to collect nectar; only those foragers which have the required strength to do so can collect nectar and in the process trip the floral mechanism and effect pollination. When floral explosion occurs, pollen is somewhat exposed and the pollen feeding foragers then collect it. The small volume of sucrose-dominant nectar with high sugar concentration in the flowers of $D$. trifoliata is an adaptation for pollination by long-tongued bees (Baker and Baker, 1983). But, the present study showed that both long and short-tongued bees trip the flowers, collect nectar, and effect pollination. Ceratina and Nomia bees are comparatively less efficient than other bees in 
tripping the flowers and effecting pollination. The butterfly, Catopsilia pyranthe, also feeds on this floral nectar and plays a minor role in pollination. The floral nectar of $D$. trifoliata may also provide a few essential and non-essential amino acids for the bees and the butterfly, but nectar analysis for these chemicals is suggested to confirm this. The flowers produce pollen in moderate amounts and it has a small amount of protein. The pollen grains being small in size and with tricolporate exine structure adhere in clumps, and hence, are easy for bees, especially honey bees, to collect and keep them in their pollen baskets (Lakshmi et al., 1997). All the bees, except Xylocopa bees, collect pollen from the dehisced anthers which are situated in the keel petals and invariably contact and pollinate the stigma. The specialized explosive floral mechanism is no doubt an important floral adaptation to discourage self-pollination and promote cross-pollination. The flowers close at the end of the day and remain so until they fall off; such a flower function may allow re-mobilization and recycling of structural proteins and nutrients from the flowers back to the plant and serve as an energy-efficient means of enhancing the overall attractiveness of the inflorescences or plant to pollinators (Gori, 1983). Therefore, the pollination system in $D$. trifoliata essentially requires insect pollinators as in Pongamia pinnata (Solomon Raju and Rao, 2006). Thrips use the flower buds of D. trifoliata for breeding and move out when the buds are open. They exhaust the nectar resource in some flowers and in effect compel insect pollinators to make multiple visits to the same or different plants in search of nectar. Such a foraging behaviour would be advantageous for the plant to maximize cross-pollination in the presence of insect pollinators.

D. trifoliata is weakly protandrous, self-compatible, and self-pollinating. In the keel petals, the stigma slightly exceeds the length of the stamens and contacts the underside of pollinator's body first when the latter visits the flower in quest of nectar and/or pollen. Such a position of stigma appears to be an adaptation for promoting cross-pollination. The pollenovule ratio of the plant also favours cross-pollination (Cruden, 1977). Individual flowers that were not tripped by insects set fruit, and hence, it is an indication of autogamy, but fruit set in this mode of pollination is negligible and it is a function of stigma gaining contact with the dehisced anthers within the intact keel petals. In insect-assisted and open-pollination modes, fruit set rate is only up to $30-31 \%$ despite the flowers being visited by insect pollinators. This low natural fruit set rate could be primarily due to scarcity of nutrient resources available to the plant. Flower bud abortion is at significant level which may additionally indicate the nutrient status of the plant. Similar situations exist also in the related species, P. pinnata (Solomon Raju and Rao, 2006). Therefore, D. trifoliata, with mixed mating system, is able to set fruit through self- and cross-pollination; the genetic variation resulting from outcrossing enables it to survive well and colonize the mangrove areas to the extent possible.

Fruits of $D$. trifoliata mature quickly in a month. Each fruit contains one-three seeds against six linearly arranged ovules in the ovary. The regulation of seed set within the fruit may be a character of the plant, or due to the scarcity of nutrient resources. Fruits do not dehisce and seeds also do not germinate while on the parent plant. The fruits are leathery and possess air cavities, the characteristics of which, enable them to float in tidal water. They settle at the parent plant if the site is partly or fully exposed or float to be dispersed if the site is inundated with tidal water. It suggests that the plant uses both self-planting and stranding strategies for dispersal and establishment. Seed release occurs when fruits absorb water and the pericarp breaks. Seeds germinate only when they reach a suitable habitat in mangroves. The importance or significance of this work cannot be highlighted in the absence of information on other species of Derris, or other genera of Fabaceae inhabiting the mangroves. 


\section{Suaeda maritima, S. monoica and S. nudiflora}

All the three Suaeda species are obligate succulent halophytes and grow well in high and salt marshes in different zonations of mangroves. Their growth, within the interiors of mangroves, is an excellent indicator of their tolerance level to high salinity. However, their growth rates vary depending on the locality, high or low salt marshes. The plants growing in high marshes are taller and more profusely branched than those growing in low marshes. Wetson et al. (2012) reported such plasticity in plant growth pattern in $S$. maritima growing in the upper and lower salt marshes. Further, these authors also reported that plants growing at the extreme tide mark without other species, grow taller with many lateral branches. Ferren and Schenk (2003) reported two varieties, richii and maritima, in S. maritima based on growth habit and seed size. Chapman (1947) also reported three principal varieties, vulgaris, macrocarpa and flexilis, based on growth habit and seed size. Redondo-Gomez et al. (2008) reported that several Suaeda species exhibit seed dimorphism and produce both brown and black seeds simultaneously and these varying colorations reflect two different dormancy and germination strategies for survival in saline habitats. Ponnamperuma (1984) explained that occurrence of different growth forms reflect different soil conditions present in high and low salt marshes due to difference in aeration levels. The high salt marshes are well-drained and infrequently inundated by tidal water and hence have stable and good soil aeration due to rapid exchange between air and soil, whereas the low salt marshes with water-logged conditions experience reduced availability of oxygen due to very slow diffusion of gases in water than in air. Further, the exchange of gases would fluctuate in both high and low salt marshes at different times due to variation in the frequency of submergence and quantum of tidal water causing inundation. As a result, the plants growing in the high and low salt marshes show different responses due to variation in soil aeration levels. All the three Suaeda species in this study did not show seed dimorphism either in size or in colour, suggesting that the variations in seed morphological characters could be situational depending on the nutrient and water levels, temperature, and other ecological factors present at the time of production of seeds in both annual and perennial Suaeda species.

Khan and Weber (2003) reported that in annuals, there is only one reproductive event in a lifetime, and this necessitates the ability to produce seeds with dormancy characteristics; when the seeds reach maturity, the environmental conditions may not be favourable for seedling growth and so germination is postponed until conditions are again more favourable. On the contrary, perennials reproduce by seeds on multiple occasions, which mean that producing genetic variations is not as paramount as it is with annuals; they may reproduce clonally, seeking to reproduce only the most successful genotype. However, as a long-term strategy, they may need to introduce new genetic individuals as and when conditions allow. In the present study, S. maritima and S. monoica are annuals and produce seeds once in their life with dormancy characteristics because their seeds germinate with a pause of five-six months from seed dispersal to seed germination. In these plants, genetic variation through sexual mode is very essential in order to withstand adverse soil conditions and produce stable populations. $S$. nudiflora is a perennial and produces seeds more than once in its life time, and hence, production of genetic variation is not very important for the production of stable populations. However, introduction of new genetic individuals as and when conditions allow is inevitable if this species is to survive and continuously produce stable populations in inhospitable habitats. 
Abeywickrama and Arulgnanam (1993) described floral sex characters in S. maritima and $S$. nudiflora. These two species produce male flowers with a small ovary and female flowers with stamens reduced or absent; the styles vary from two to three. In S. monoica, each flower cluster consists of a large male flower with rudimentary ovary surrounded by smaller female flowers with or without staminodes. Individual plants produce only female flowers. This study disapproves these, because all the three Suaeda species produce only bisexual flowers without styles. S. maritima and S. monoica flowers produce three sessile stigmas while $S$. nudiflora produces two sessile stigmas. Further, the inflorescences are characteristically axillary in S. maritima and S. monoica, while they are borne both in the axils and terminally in $S$. nudiflora. The clustered cymes produce varying number of flowers with each Suaeda species, they are 9-18 in S. maritima, five-eight in S. monoica, and two-four in S. nudiflora.

Rea (1969) and Kubitzki et al. (1993) show that polygamy occurs in many species of Chenopodiaceae. Gynomonoecy, in combination with protandry or protogyny, occurs in some species. Kubitzki et al. (1993) show that the presence of inconspicuous, minute, frequently perianth-less, and mostly nectar-less flowers are considered as adaptations for anemophily. Typical features of anemophily such as dusting pollen, waving, limp-filaments, or simultaneous flower opening are usually required in order to be uniformly anemophilous. Zandonella (1977) noted that a switch-over from entomophily to anemophily, or reverse, might have occurred in this family. Dalby (1962) stated self-pollination also frequently occurs in various genera. One such genus is Salicornia in which the ripe dehiscing anthers stay in contact with the presumably receptive stigmas, and in effect, selfing occurs. Kubitzki et al. (1993) felt that probably various degrees of balance between anemophily and self-pollination can be found in the members of this family. Dem'yanova (1977) reported that S. microphylla, S. physophora, S. acuminate, and S. linifolia are predominantly anemophilous; entomophilous also exists but it has no significant importance. The flowers receive visits of Halictus bees during staminate phase, by which time, the stigma begins to wither and does not accept pollen. Keighery (1979) reported that honey bees and syrphid flies collect pollen from the flowers of Suaeda australis, but this author did not state whether they are pollinators or not. Chapman (1947) mentioned that S. maritima flowers are homogamous or feebly protandrous, autonomous autogamy is easily possible. The flowers are nectar-less and, hence, insect activity is absent. Bassett and Crompton (2011) recorded that S. maritima is wind-pollinated. Naskar and Mandal (1999) reported that S. maritima is pollinated by wind, water currents, and flies.

All the three Suaeda species are nectariferous and offer nectar in minute to trace amounts. The flowers are dichogamous with protogyny. They are pistillate during mature bud stage and staminate after anthesis, this prevents autonomous or facilitated selfing within the flower. This sexual system is almost typical of temporal dioecy. Cruden and Hermann-Parker (1977) coined the term "temporal dioecism" to describe the pattern of sexual alternation within the individual plants to facilitate outcrossing through the promotion of xenogamy. The sexual system functional in the Suaeda species is a type of temporal dioecy. In these species, the strong dichogamy appears to have evolved to promote outcrossing, however, both pistillate and staminate phase flowers are available at any given point within the individual plants facilitating the occurrence of geitonogamy. Therefore, the Suaeda species seem to have evolved temporal dioecy to promote outcrossing through xenogamy while keeping the option open for selfing through geitonogamy. The fruit set recorded in open-pollinations substantiates the functionality of such a sexual system. This sexual system is essential for these species to produce seeds in isolated individuals in news areas in order to build up their populations. 
Renner and Feil (1993) stated the plants that possess morphological traits fulfilling the aerodynamic requirements of pollen dispersal and capture, favour the evolution of anemophily. Wind pollination evolves when pollinators are scarce, absent, or deliver poor pollen when plants colonize areas with low insect abundance (Weller et al., 1998; Gomez and Zamora, 1996). Anemophilous plants do not invest in resources that attract pollinators, such as showy flowers, nectar, and scent. Instead, they produce a big quantity of light, dry pollen from small, plain flowers that can be carried by wind. Female structures are adapted to capture the passing pollen from the air, but the majority of pollen goes waste. Niklas (1985) stated that plants with small, colourless, odourless, and nectar-less flowers, reduced or no perianth, projecting exserted stamens away from the boundary layer of main flower to higher wind speeds, production of large quantity of light, dry and dusty pollen, permitting the removal of pollen, and exposed large, hairy and feathery stigma to capture pollen, are adapted for anemophily. In all three Suaeda species, the flowers have a combination of anemophilous and entomophilous traits. The anemophilous traits are odourless, unattractive flowers with inconspicuous perianth, the exserted stamens projected out of the perianth and light, dry and dusty pollen, while entomophilous traits are production of nectar, dorsi-fixed stamens, production of moderate quantity of pollen, and promiscuity of flower for nectar and pollen collection for insects. Anemophily is effective, especially in high salt marshes, due to the occurrence of moderate to high wind speeds in the mangrove. The pollen deposition by wind on the stigmas can be easily recorded and the leaves also get coated with pollen despite their succulent nature. Insects pollinate the flowers while collecting the forage from pistillate and staminate phase flowers. Bees visit only staminate flowers due to the availability of both nectar and pollen; while approaching these flowers, affect either geitonogamy or xenogamy because of the clustered flowers. Wasps, flies, and ants probe pistillate phase mature buds and staminate phase flowers of the concerned plant species indiscriminately, but the pistillate phase flowers are nonrewarding while the staminate phase flowers are rewarding. As a result, these insects affect geitonogamy and xenogamy. The Chrysocoris beetle is a voracious pollen feeder and deprives the flowers of pollen in S. maritima, its pollen feeding activity is indirectly compels the bees to collect pollen from different plants and such a foraging behavior results in the promotion of xenogamy. Further, thrips in all the three species and one insect in immature stage in case of $S$. nudiflora, deplete both nectar and pollen considerably and such state of floral rewards drive all the insect species, except ants, to make frequent inter-plant visits within the species and across Suaeda species. This leads to the promotion of outcrossing through xenogamy. The occurrence of these species in the same area, and their simultaneous flowering, facilitates the insects to deposit mixed pollen consisting of the pollen of all the three species on their stigmas and this pollen discounting diminishes outcross siring success. In this context, it is to be stated that insect activity is not very intense on these plant species, it is prominent on $S$. maritima and $S$. monoica, while it is not so in $S$. nudiflora, due to the production of very inconspicuous flowers when compared to the other two species. Pollen discounting did not show any affect on seed set rate and it is reflected in the very high fruit set rate in open-pollinations. This could be because of requirement of a few viable pollen grains for stigmas to produce a single seed per flower. Further, water currents also disperse pollen and pollinate flowers within and between plants of all the three species in inundated or submerged localities. In these localities, anemophily or entomophily is not very effective due to wet state of pollen, or flowers, or even plants. These three Suaeda species use a combination of pollination by wind, insects and water currents. The function of three pollination syndromes gives flexibility to maximize fruit or seed set rate through outcrossing as well as selfing through geitonogamy (Culley et al., 2002). 
Chenopodiaceous seeds are dispersed by wind, water, and animals (Ridley, 1930). Chapman (1947) stated that in S. maritima, seed germination occurs from March onwards and fruits disperse from October onwards. Fruit dispersal occurs by tides and they can float for three days and then settle. In the present study also, it is found that in all the three Suaeda species, whole plant breaks off and rolls on the floor while shedding its diasporas. Fruits with seeds intact and/or seeds shed from fruits float on water due to their ability for buoyancy. The fruits and seeds thus disperse, settle in the entire extent of salt marshes or coastal areas, and germinate in mid-summer season when salinity is very high in high and low salt marshes.

Jones and Blum (1983) show that pyrrolizidine alkaloids play a key role in host-plant selection and, as a sex pheromone in certain danaid butterflies. These butterflies apply from their proboscides a fluid able of dissolving alkaloids and then re-imbibe it. These butterflies store alkaloids, for defence (Edgar et al., 1976, 1979; Rothschild et al., 1979; Conner et al., 1981). Owen (1971) show that danaine butterflies use withered and damaged plants and floral nectar as sources of alkaloids. $D$. chrysippus uses the pyrrolizidine alkaloids to protect from its predators and synthesize the courtship pheromone. Alkaloids play an important role to protect the most vulnerable stage, the egg (Meinwald, 1990). This butterfly species, and also $D$. plexippus, when equipped with these alkaloids, have been experimentally proved to be unpalatable to their predators by Edgar et al. (1976). Boppre (1983) reported that Tirumala petiverana collects sap from Heliotropium pectinatum in East Africa. Mathew and Anto (2007) reported that $T$. limniace uses the pyrrolizidine alkaloids to deter its predators, the garden lizards. In the present study, the nymphalid butterflies, Danaus genutia, D. chrysippus, the lycaenid Euchrysops cnejus, and the hesperiid, Borbo cinnara, have been found to collect sap from the leaves before flowering and dry fruiting branches of all the three Suaeda species. The presence of alkaloids, triterpenoids, sterols, and various other chemicals have been reported in S. maritima, S. monoica, and S. nudiflora (Al-Mohammadi et al., 2005; Ravikumar et al., 2011; Satyavani et al., 2012; Singh et al., 2012; Suganthy et al., 2009; Gurudeeban et al., 2011). Therefore, the Suaeda species studied now appear to be an important source of alkaloids for all the recorded butterfly species and the latter use them to deter their predators.

The genus Suaeda has both $\mathrm{C}_{3}$ and $\mathrm{C}_{4}$ photosynthetic pathways, both categories of species commonly grow side by side; $\mathrm{C}_{4}$ species are mostly annuals in central Asia (Glagoleva et al., 1990). $C_{4}$ pathway is an adaptive mechanism to grow in stressful environment. These species grow abundantly in drier and more saline sites and persist throughout the dry season due to their succulence (Fisher et al., 1997). S. maritima is a $C_{3}$ species with austrobassioid leaf anatomy and colonizes all areas where perennial species are absent due to sensitivity to competitive interactions (Yeo and Flowers, 1980; Mateu Andres, 1989). S. monoica and S. nudiflora are $\mathrm{C}_{4}$ species and grow abundantly in hot, dry, high-light saline environments (Shomer-Ilan et al., 1975; Ehleringer and Monson, 1993; Singh et al., 2004; Patel and Pandey, 2009). In the present study, S. maritima and S. monoica are annuals while $S$. nudiflora is a perennial; all the three grow side by side in both high and low salt marshes. S. nudiflora is dominant particularly in drier, saline areas; its successful growth in such areas could be related to $\mathrm{C}_{4}$ photosynthetic pathway. Further, $S$. maritima and $S$. monoica have been found to grow mostly in areas where $S$. nudiflora does not grow. Such a growth pattern appears to be related to sensitivity of the first two species to competitive interactions arising from the perennial species, $S$. nudiflora, which is usually available throughout the year and displays extensive mat-forming growth. Nevertheless, $\mathrm{C}_{4}$ species $S$. monoica and $S$. nudiflora, can be successfully used for eco-restoration in saline areas where other species do not grow. 
Manousaki and Kalogerakis (2011) reported that halophytes are more efficient in withstanding and adapting themselves to several abiotic factors due to several inherent basic biochemical tolerance mechanisms when compared to glycophytic plants. They are naturally better adapted to cope with environmental stresses, including heavy metals, compared to saltsensitive crop plants commonly chosen for phytoremediation purposes for the removal of heavy metals from soils. They are potentially ideal plants for phyto-extraction or phyto-stabilization applications of heavy metal polluted soils, and moreover, of heavy metal polluted soils affected by salinity. Some salt-excreting halophytes use their excretion mechanism in order to remove the excess of toxic metal ions from their sensitive tissues, and hence, act as biological pumps for heavy metals. Phyto-desalination has attracted much interest for the desalination of soils with the use of salt-accumulating halophytes which receive and accumulate high concentrations of salt in their aboveground tissues and consequently saline soils can be improved by harvesting the plants. Cherian and Reddy (2003) stated that salinity is a major problem in irrigated agriculture especially in the arid and semiarid environments. While glycophytes undergo growth inhibition in saline environments either due to a decline in water uptake caused by the increase in external osmotic pressure or due to ionic imbalance in the cytosol, halophytes evolved mechanisms for controlled influx of sodium and chloride ions to be used for their benefit in a saline environment. Reddy et al. (2010) reported that halophytes are widely used due to their high economic values like fodder, oil, fuel, and so forth, and, also for ecological interests like soil desalination, dune fixation, phyto-remediation, landscaping and ornamental purpose. Further, domestication of halophytes as potential crop plants for biomass production, is an emerging field towards rehabilitation of salinized lands in semi-arid and arid areas. Soils adjacent to the coastal areas under irrigation or otherwise get enriched with various materials including hazardous elements from the discharges of industrial effluents, which in turn, pose a great problem for the reclamation of soils and for their use in cultivation. Manousaki and Kalogerakis (2011) reported that S. maritima accumulates high concentrations of salt in its aboveground tissues, and consequently, saline soils can be upgraded by harvesting the plants on a regular basis. Ravindran et al. (2007) also reported that S. maritima accumulates high concentrations of salts in its tissues and reduces salts in the saline land to a great extent. These authors called it a salt accumulating halophyte and it can be used successfully to accumulate salt in highly salinized areas for crop production after a few repeated cultivations and harvests. Reddy et al. (2010) also mentioned that $S$. nudiflora accumulates and sustains the salinity levels nearby double that of seawater. It could be cultivated for its economic importance, even on highly polluted soils for reclamation. Further, it is also used as a source of biological salt or oil. Singh et al. (2004) reported that the seeds of S. nudiflora contain approximately 30-35\% oil, and hence, has the potential as a future oil seed crop. It is highly suitable for producing high protein biomass in saline soils with its $\mathrm{C}_{4}$ photosynthetic pathway. Therefore, the studied Suaeda species can be used to extract salt, desalinate saline soils, and use such soils for normal plantation or cultivation. Salinization is a serious problem confronting sustainable agriculture in irrigated production systems in semi-arid and arid regions where plant growth is directly affected by high levels of sodium chloride and other salts (Marschner, 1986). In India, about 30 million ha of coastal land is still barren and uncultivable because of bad soil affected by salinity (Singh and Surendra, 1994). In this context, it is quite appropriate to consider Suaeda species as potential desalinating agents for highly saline soils in order to convert bad soils into fertile soils for crop production. Further, they can also be used for the clean-up of polluted soils through phyto-remediation programs. 


\section{CONCLUSIONS}

Clerodendrum inerme, Derris trifoliata, Suaeda maritima, S. monoica, and S. nudiflora are hermaphroditic, self-compatible, and exhibit mixed breeding systems which are primarily adapted for cross-pollination. All these species are vector-dependent for both self- and cross-pollination. C. inerme exhibits dichogamy and herkogamy. It is principally pollinated by the hawkmoth, Macroglossum gyrans. D. trifoliata is feebly protandrous and the flowers close back by the end of the day of anthesis. All three Suaeda species are dichogamous and strongly protogynous; the flowers are pistillate during mature bud stage and staminate on the day of anthesis suggesting a type of temporal dioecy. C. inerme and $D$. trifoliata are principally entomophilous. The Suaeda species are principally anemophilous, followed by entomophily in high salt marshes, while they are primarily pollinated by water currents and also by insects to a lesser degree. All these species are nectariferous and offer pollen and nectar as floral rewards to insect pollinators. The Suaeda species do not offer either nectar or pollen during pistillate phase due to closed state of mature buds, but offer both the rewards to insect pollinators during staminate phase, which occurs after anthesis.

In C. inerme, birds such as Acridotheres tristis (Indian Myna), Corvus splendens (House Crow), Corvus macrorhynchos (Jungle Crow), and Turdoides caudatus (Common Babbler) disperse nutlets or seeds during early winter season. Seed germination occurs in June and seedlings grow gradually to produce new plants. In $D$. trifoliata, the fruits are leathery and possess air cavities which enable them to float in tidal water. They settle at the parent plant if the site is partly or fully exposed, or float for dispersal if the site is inundated with tidal water. Seed release occurs when fruits absorb water and the pericarp breaks. Seeds germinate only when they reach a suitable habitat in mangroves. In the Suaeda species, the whole plant breaks off and rolls on the floor while shedding its diaspores. Fruits with seeds intact and/or seeds shed from fruits float on water due to their ability for buoyancy. The fruits and seeds thus disperse, settle in the entire extent of salt marshes or coastal areas, and germinate in mid-summer season when salinity is very high in high and low salt marshes. S. maritima is a $\mathrm{C}_{3}$ species, while $S$. monoica and $S$. nudiflora are $\mathrm{C}_{4}$ species; the last two species can be successfully used for eco-restoration in saline areas where other species do not grow. All species can also be used to extract salt, desalinate saline soils, and use such soils for normal plantation or cultivation. 


\section{ACKNOWLEDGEMENT}

The authors the Andhra University, Visakhapatnam, India for providing all facilities to carry out this research work. 


\section{REFERENCES}

1. Abeywickrama B. A. and Arulgnanam P., 1993 - The Coastal Plants of Sri Lanka, Part I, UNESCO: Man and the Biosphere National Committee for Sri Lanka, 20, Natural Resources, Energy and Science Authority of Sri Lanka, Colombo, 19.

2. Al-Mohammadi S. S., Al-Khateeb E. and Al-shamma S., 2005 - Phytochemical investigation of Suaeda baccata (Chenopodiaceae), Asian Journal of Pharmaceutical Sciences, 2, 51-57.

3. Azuma H., Toyota M., Asakawa Y., Takaso T. and Tobe H., 2002 - Floral scent chemistry of mangrove plants, Journal of Plant Research, 115, 47-53.

4. Baker H. G. and Baker I., 1973 - Some anthecological aspects of evolution of nectar-producing flowers, particularly amino acid production in nectar, in Heywood V. H. (ed.), Taxonomy and Ecology, Academic Press, London, 243-264.

5. Baker H. G. and Baker I., 1983 - A review of the chemistry of floral nectar, in The Biology of Nectaries, Bentley B. and Elias T. (eds), Columbia University Press, New York, 126-152.

6. Baker H. G., Bawa K. S., Frankie G. W. and Opler P. A., 1983 - Reproductive biology of plants in tropical forests, in Golley F. B. (ed.), Ecosystems of the World 14 A, Tropical rain forest ecosystems: Structure and Function, Elsevier Scientific Publishing Company, New York, 183-215.

7. Barrows E. M., 1976 - Nectar robbing and pollination in Lantana camara (Verbenaceae), Biotropica, 8, 132-135.

8. Barrows E. M., 1980 - Robbing of exotic plants by introduced carpenter and honey bees in Hawaii, with comparative notes, Biotropica, 12, 23-29.

9. Bassett I. J. and Crompton C. W., 2011 - The genus Chenopodium in Canada, Canadian Journal of Botany, 60, 586-610.

10. Boppre M., 1983 - Adult Lepidoptera "feeding" at withered Heliotropium plants (Boraginaceae) in East Africa, Ecological Entomology, 6, 449-452.

11. Byragi Reddy T. and Subba Reddi C., 1995 - Butterfly pollination of Clerodendrum infortunatum (Verbenaceae), Journal of Bombay Natural History Society, 92, 166-173.

12. Castro S., Silveira P. and Navarro L., 2008 - Consequences of nectar robbing for the fitness of a threatened plant species, Plant Ecology, 199, 201-208.

13. Castro S., Silveira P. and Navarro L., 2009 - Floral traits variation, legitimate pollination, and nectar robbing in Polygala vayredae (Polygalaceae), Ecological Research, 24, 47-55.

14. Chapman V. J., 1947 - Suaeda maritima (L.) Dum., Journal of Ecology, 35, 293-302.

15. Cherian S. and Reddy M. P., 2003 - Evaluation of $\mathrm{NaCl}$ tolerance in the callus cultures of Suaeda nudiflora Moq., Biologia Plantarum, 46, 193-198.

16. Chethana G. S., Hari Venkatesh K. R. and Gopinath S. M., 2013 - Review on Clerodendrum inerme, Journal of Pharmaceutical and Scientific Innovation, 2, 38-40.

17. Chiou-Rong S., Yong J. W. H. and Yang Y. P., 2005 - The Brugueira species in the mangroves of Singapore, Especially on the new record and the rediscovery, Taiwania, 50, 251-260.

18. Clarke P. J. and Meyerscough P. J., 1991 - Floral biology and reproductive phenology of Avicennia marina in south eastern Australia, Australian Journal of Botany, 39, 283-293.

19. Conner W. E., Eisner T., Vander Meer R. K., Guerrero A., Ghitingelli D. and Meinwald J., 1981 - Precopulatory sexual interaction in an arctiid moth (Utetheisa ornatrix): Role of a pheromone derived from dietary alkaloids, Behavioural Ecology and Sociobiology, 9, 227-235.

20. Coupland G. T., Paling Eric I. and McGuinness Keith A., 2006 - Floral abortion and pollination in four species of tropical mangroves from northern Australia, Aquatic Botany, 84, 151-157.

21. Cruden R. W., 1977 - Pollen-ovule ratios: a conservative indicator of breeding systems in flowering plant, Evolution, 31, 32-46.

22. Cruden R. W. and Herrmann-Parker S., 1977 - Temporal dioecism: an alternative to dioecism? Evolution, 31, 863-866. 
23. Cruden R. W., Hermann S. M. and Peterson S., 1983 - Patterns of nectar production and plantpollinator coevolution, in Bentley B. and Elias T. (eds), Biology of Nectaries, Columbia University Press, New York, 80-125.

24. Culley T. M., Wellder S. G. and Sakai A. K., 2002 - The evolution of wind pollination in angiosperms, Trends in Ecology and Evolution, 17, 361-369.

25. Dafni A., Kevan P. G. and Husband B. C. (eds), 2005 - Practical Pollination Biology, Enviroquest Ltd., Ontario, 315.

26. Dalby D. H., 1962 - Chromosome number, morphology and breeding behavior in the British Salicornieae, Watsonia, 5, 150-162.

27. Davey J. E., 1975 - Note on the mechanisms of pollen release in Bruguiera gymnorrhiza, Journal of South African Botany, 41, 269-272.

28. Davis M. A., 1987 - The role of flower visitors in the explosive pollination of Thalia geniculata (Marantaeae), a Costa Rican marsh plant, Bulletin of Torrey Botanical Club, 114, 134-138.

29. Dem'yanova E. I., 1977 - Flowering and pollination ecology of some species of Suaeda of southeast Kazakh, USSR, Biologicheskie Nauki (Moscow), 20, 91-96.

30. Edgar J. A., Boppre M. and Schneider D., 1979 - Pyrrolizidine alkaloid storage in African and Australian danaid butterflies, Experientia, 35, 1447-1448.

31. Edgar J. A., Cockrum P. A. and Frahn J. L., 1976 - Pyrrolizidine alkaloids in Danaus plexippus L. and Danaus chrysippus L., Experientia (Basel), 32, 1535-1537.

32. Ehleringer J. R. and Monson R. K., 1993 - Evolutionary and ecological aspects of photosynthetic pathway variation, Annual Review of Ecology and Systematics, 24, 411-439.

33. Feehan J., 1985 - Explosive flower-opening in ornithophily: a study of pollination mechanisms in some Central African Loranthaceae, Botanical Journal of Linnean Society, 90, 129-144.

34. Fenster C. B., 1991 - Gene flow in Chamaecrista fasciculata (Leguminosae), Evolution, 45, 398-422.

35. Fernandes M. E. B., 1999 - Phenological patterns of Rhizophora L., Avicennia L. and Laguncularia Gaertn. f. in Amazonian mangrove swamps, Hydrobiologia, 413, 53-62.

36. Ferren W. R. Jr. and Schenk H. J., 2003 - Suaeda Forsskal ex Gmelin J. F., in Flora of North America, North of Mexico, FNA Editorial Committee, 4, Magnoliophyta: Caryophyllidae, I, Oxford University Press, New York, 390-398.

37. Fisher D. D., Schenk H. J., Thorsch J. A. and Ferren Jr. W. R., 1997 - Leaf anatomy and subgeneric affiliations of $\mathrm{C}_{3}$ and $\mathrm{C}_{4}$ of Suaeda (Chenopodiaceae) in North America, American Journal of Botany, 84, 1198-1210.

38. Ge J., Cai B. and Lin P., 2003 - Mating system and out crossing rates of four Bruguiera gymnorrhiza populations of mangrove, China, Nature and Science, 1, 42-48.

39. Glagoleva T. A., Voznesenskaya E. V., Kol'chevskii K. G., Kocharya N. I., Pakhomova M. V., Chulanovskaya M. V. and Gamaley Y. V., 1990 - Structural-functional characteristics of halophytes of the Ararat Valley, Soviet Plant Physiology, 37, 822-829.

40. Gomez J. M. and Zamora R., 1996 - Wind pollination in high-mountain populations of Hormathophylla spinosa (Cruciferae), American Journal of Botany, 83, 580-585.

41. Gori F. G., 1983 - Post-pollination phenomena and adaptive floral changes, in Jones C. E. and Little R. J. (eds), Handbook of Experimental Pollination Biology, Scientific and Academic Editions, New York, 32-45.

42. Gottsberger G., 1989 - Floral Ecology: Report on the years 1985 (1984) to 1988, Progress in Botany, 50, 352-379.

43. Guitian J., Sanchez J. J. and Guitian P., 1994 - Pollination ecology of Petrocoptis grandiflora Rothm. (Caryophyllaceae); a species endemic to the north-west part of the Iberian peninsula, Botanical Journal of Linnean Society, 115, 19-27. 
44. Gurudeeban S., Ramanathan T., Satyavani K. and Dhinesh T., 2011 - Standardization of DNA isolation and PCR protocol for RAPD analysis of Suaeda sp., Asian Journal of Biotechnology, 3, 486-492.

45. Harborne J. B., 1973 - Phytochemical Methods. Chapman and Hall, London, 288.

46. Inouye D. W., 1983 - The ecology of nectar robbing, in Bentley B. and Elias T. (eds), The Biology of Nectaries, Columbia University Press, New York, 153-173.

47. Ivor M., 1994 - Field Guide, Butterflies of Southern Africa, Struik Publishers, Cape Town, 210.

48. Jonathan K. H., 2009 - Reproductive ecology of some viviparous and non-viviparous mangrove plant species, PhD Thesis, Andhra University, Visakhapatnam, 222.

49. Jonathan K. H. and Solomon Raju A. J., 2009 - Insect pollination and self-planting seed dispersal strategy in the true viviparous mangrove tree species Ceriops tagal (Perr.) Robinson C. B. (Rhizophoraceae), Journal of Threatened Taxa, 1, 133-140.

50. Jones T. H. and Blum M. S., 1983 - Arthropod alkaloids: distribution, functions and chemistry, in Pelletier S. W. (ed.), Alkaloids: Chemical and Biological Perspectives, Wiley, New York, 34-84.

51. Juncosa A. M. and Tomlinson P. B., 1987 - Floral development in mangrove Rhizophoraceae, American Journal of Botany, 74, 1263-1279.

52. Keighery G. J., 1979 - Insect pollination of Suaeda australis (Chenopodiaeae), Western Australian Naturalist, 14, 154

53. Keng H., 1990 - The Concise Flora of Singapore: Gymnosperms and Dicotyledons, Singapore University Press, Singapore, 222.

54. Khan M. A. and Weber D. J. (eds), 2006 - Ecophysiology of high salinity tolerant plants, Springer, Netherlands, ISBN 978-1-4020-4018-4, 399

55. Kubitzki K., Rohwer J. G. and Bittrich V., 1993 - Flowering plants- Dicotyledons: Magnoliid, Hamamelid and Caryophyllid Families (The Families and genera of Vascular Plants), Springer Science and Business Media, 653.

56. Kunte K., 2007 - India -A Lifescape. Butterflies of Peninsular India, Universities Press, 254.

57. Lacerda L. D., Conde J. E. and Kjerfve B., 2002 - American Mangroves, in Lacerda L. D. (ed.), Mangrove Ecosystems: Function and Management, Springer, Berlin, 1-62.

58. Lakshmi M., Rajalakshmi S., Parani M., Anuratha C. S. and Parida A., 1997 - Molecular phylogeny of mangroves, I, Use of molecular markers in accessing the intraspecific genetic variability in the mangrove species Acanthus ilicifolius Linn. (Acanthaceae), Theoretical and Applied Genetics, 94, 1121-1127.

59. Lorence D. H. and Flynn T., 1997 - New naturalized plant records for Kauai, Bishop Museum Occasional Papers, 49, 9-13.

60. Manousaki E. and Kalogerakis N., 2011 - Halophytes present new opportunities in phytoremediation of heavy metals and saline soils, Industrial and Engineering Chemistry Research, 50, 656-660.

61. Marie-Victorin F., 1919 - Flore Laurentinne, Les Freres des ecoles chretiennes, Montreal, 217.

62. Marschner H., 1986 - Mineral nutrition of higher plants, Academic Press, London, 674.

63. Mateu Andres I., 1989 - Anatomia foliar en plantas de saladares mediterraneos costeros, Dicotiledoneas, Candollea, 44, 435-452.

64. Mathew G. and Anto M., 2007 - In situ conservation of butterflies through establishment of butterfly gardens: A case study at Peechi, Kerala, India, Current Science, 93, 337-347.

65. McMullen C. K., 2011 - Nocturnal and diurnal pollination of Clerodendrum molle (Verbenaceae) in the Galapagos Islands, Plant Systematics and Evolution, 292, 15-23.

66. Meerabai G., 2014 - A study on co-evolutionary relationship of four plants with their butterfly pollinators on the basis of their nectar physiology, Environment and Natural Resource Research, 4, 65-69. 
67. Meeuse B. J. D., 1961 - The Story of Pollination, The Ronald Press Company, New York.

68. Meinwald J., 1990 - Alkaloids and isoprenoids as defensive and signaling agents among insects, Pure and Applied Chemistry, 62, 1325-1328.

69. Mosquin T., 1985 - The explosive pollination mechanism in the pop flower, Chamaepericlymenum (Cornaceae), Canadian Field-Naturalist, 99, 1-5.

70. Naskar K. and Mandal R., 1999 - Ecology and Biodiversity of Indian Mangroves, Daya Publishing House, New Delhi, 754.

71. Niklas K. J., 1985 - The aerodynamics of wind-pollination, Botanical Review, 51, 328-386.

72. $\quad$ Owen D. F., 1971 - Tropical Butterflies, Clarendon Press, Oxford.

73. Pandit S. and Choudhury B. C., 2001 - Factors effecting pollinator visitation and reproductive success in Sonneratia caseolaris and Aegiceras corniculatum in the mangrove forest in India, Journal of Tropical Ecology, 17, 431-447.

74. Parani M., Lakshmi M. and Senthilkumar P., 1998 - Molecular phylogeny of mangroves, V, Analysis of genome relationships in mangrove species using RAPD and RFLP markers, Theoretical and Applied Genetics, 97, 617-625.

75. Patel N. T. and Pandey A. N., 2009 - Effect of soil salinity on growth, water status and nutrient accumulation in seedlings of Suaeda nudiflora (Chenopodiaceae), Anales de Biologia, 31, 6170.

76. Pleasants J. M., 1983 - Nectar production in Ipomopsis aggregata (Polemoniaceae), American Journal of Botany, 70, 1468-1475.

77. Plitmann U., Raven P. H. and Breedlove D. E., 1973 - The systematics of Lepezieae (Onagraceae), Annals of Missouri Botanical Garden, 60, 478-563.

78. Ponnamperuma F. N., 1984 - Effects of flooding on soils, in Kozlowski T. T. (ed.), Flooding and plant growth, Academic Press, New York, 9-45.

79. Primack R. B., Duke N. C. and Tomlinson P. B., 1981 - Floral morphology in relation to pollination ecology in five Queensland coastal plants, Austrobaileya, 4, 346-355.

80. Proctor M. and Yeo P., 1972 - The Pollination of Flowers, Taplinger, New York.

81. Rama Mohan K., 2009 - Reproductive ecology of some true viviparous and crypto-viviparous mangrove tree species, PhD Thesis, Andhra University, Visakhapatnam.

82. Ravikumar S., Gnanadesigan M., Inbaneson S. J. and Kalairasi A., 2011 - Hepatoprotective and antioxidant properties of Suaeda maritima (L.) Dumort ethanolic extract on concanavalin-A induced hepatotoxicity in rats, Indian Journal of Experimental Biology, 49, 455-460.

83. Ravindran K. C., Venkatesa K., Balakrishnan V., Chellappan K. P. and Balasubramanian T., 2007 - Restoration of saline land by halophytes for Indian soils, Soil Biology and Biochemistry, 39, 2661-2664.

84. Rea J., 1969 - Biologia floral de la quinua (ch. Quinoa), Turrialba, 19, 91-96.

85. Reddy M. S., Joshi M. P., Dave S. P., Adimurthy S., Susarla V. S., Mehta A. S., Subba Rao P. V., Reddy M. P. and Ramachandraiah G., 2010 - Bromide tolerance in plants: a case study on halophytes of Indian coast, SRX Ecology, 2010, 1-6.

86. Redondo-Gomez S., Mateos-Naranjo E., Cambrolle J., Luque T., Figueroa M. E. and Davy A. J., 2008 - Carry-over of differential salt tolerance in plants grown from dimorphic seeds of Suaeda splendens, Annals of Botany, 102, 103-112.

87. Renner S. S. and Feil J. P., 1993 - Pollination of tropical dioecious angiosperms, American Journal of Botany, 80, 1100-1107.

88. Ridley H. N., 1930 - The dispersal of plants throughout the world, Reeve and Company, Ashford, Kent, 744

89. Rohitash R. and Jain K., 2010 - Reproductive Biology of Clerodendrum splendens (Verbenaceae), Advances in Bioresearch, 1, 84-86.

90. Rothschild M., Alpin R. T., Cockrum P. A., Edgar J. A. and Fairweather P., 1979 Pyrrolizidine alkaloids in Arctiid moths (Lepidoptera) with a discussion on host plant relationships and the role of these secondary plant substances in the Arctiidae, Biological Journal of Linnean Society, 12, 305-326. 
91. Roubik D. W., 1995 - Pollination of cultivated plants in the tropics, FAO Agricultural Services Bulletin, 118.

92. Roy S. D. and Krishnan P., 2005 - Mangrove stands of Andamans vis-à-vis tsunami, Current Science, 89, 1800-1804.

93. Sadasivam S. and Manickam A., 1997 - Biochemical Methods, New Age Intl. Pvt. Ltd., New Delhi, 256.

94. Saenger P., 2002 - Mangrove Ecology, Silviculture and Conservation, Kluwer Academic Publishers, Dordrecht, the Netherlands, ISBN 978-94-015-9962-7, 228

95. Sakamoto R. L., Ito M. and Kawakubo N., 2012 - Contribution of pollinators to seed production as revealed by differential pollinator exclusion in Clerodendrum trichotomum (Lamiaceae), PLOS ONE, 7, 168, 153-165.

96. Satyavani K., Gurudeeban S., Ramanathan T. and Balasubramanian T., 2012 - Toxicity study of silver nanoparticles synthesized from Suaeda monoica on Hep-2 cell line, Avicenna Journal of Medical Biotechnology, 4, 35-38.

97. Satynarayana B., Raman A. V. and Dehairs F., 2002 - Mangrove floristic and zonation patterns of Coringa, Kakinada Bay, East Coast of India, Wetlands Ecological Management, 10, $25-39$.

98. Shamim A. L., Rahmani M. O., Uddin M. Z., Hassan M. A. and Begum M., $2010-$ Reproductive biology of three medicinal plants, Bangladesh, Journal of Plant Taxonomy, 17, 69-78.

99. Shomer-Ilan A., Beer S. and Waisel Y., 1975 - Suaeda monoica, a $\mathrm{C}_{4}$ plant without typical bundle sheaths, Plant Physiology, 56, 676-679.

100. Singh R. P. and Surendra S., 1994 - Sustainable development of the Indian arid zone: a research perspective, Vedams Books Ltd., New Delhi, 335.

101. Singh A., Chikara J. and Pandya J. B., 2004 - Plant regeneration from callus cultures in Suaeda nudiflora (Willd.) Moq., Indian Journal of Biotechnology, 3, 454-456.

102. Singh S., Sharma S. K. R. and Manni R., 2012 - Pharmacognostical standardization of stem of Suaeda maritima (L.) Dumort., International Journal Pharmacy and Pharmaceutical Sciences, 4, 304-306.

103. Solomon Raju A. J., 1990 - Observations on the floral biology of certain mangroves, Proceedings of Indian National Science Academy, B56, 367-374.

104. Solomon Raju A. J. and Jonathan K. H., 2008 - Reproductive ecology of mangrove trees Ceriops decandra (Griff.) Ding Hou and Ceriops tagal (Perr.) Robinson C. B. (Rhizophoraceae), Acta Botanica Croatica, 67, 201-208.

105. Solomon Raju A. J. and Rao S. P., 2006 - Explosive pollen release and pollination as a function of nectar-feeding activity of certain bees in the biodiesel plant, Pongamia pinnata (l.) Pierre (Fabaceae), Current Science, 90, 960-967.

106. Solomon Raju A. J., Subba Reddi C. and Sujatha B., 1994 - Pollination in mangrove plants, Journal of Nature Conservation, 6, 89-96.

107. Solomon Raju A. J., Jonathan K. H. and Vijaya Lakshmi A., 2006 - Pollination biology of Ceriops decandra (Griff.) Ding Hou (Rhizophoraceae), an important true viviparous mangrove tree species, Current Science, 91, 1235-1238.

108. Spalding M., Blasco F. and Field C., 1997 - World Mangrove Atlas, The International Society for Mangrove Ecosystems, Okinawa, Japan, 178.

109. Subba Reddi C. and Solomon Raju A. J., 1997 - Reproductive biology of three mangrove plant species, Indian Journal of Forestry, 20, 153-157.

110. Suganthy N., Pandian S. K. and Devi K. P., 2009 - Cholinesterase inhibitory effects of Rhizophora lamarckii, Avicennia officinalis, Sesuvium portulacastrum and Suaeda monoica: mangroves inhabiting an Indian coastal area (Vellar Estuary), Journal of Enzyme Inhibition and Medicinal Chemistry, 24, 702-707.

111. Taylor N., 1942 - The Practical Encyclopedia of Gardening, Garden City Publ. Co., New York.

112. Tomlinson P. B., 1986 - The Botany of Mangroves, Cambridge University Press, 419. 
113. Tomlinson P. B., Primack R. B. and Bunt J. S., 1979 - Preliminary observations on floral biology in mangrove Rhizophoraceae, Biotropica, 11, 256-277.

114. Van der Pijl L., 1954 - Xylocopa and flowers in the Tropics, I-III, Proceedings of the Koniklije Nederlandse Akademie van Wetenschappen: Series C., 57, 413-423, 514-562.

115. Wang L., Mu M., Li X., Lin P. and Wang W., 2011 - Differentiation between true mangroves and mangrove associates based on leaf traits and salt contents, Journal of Plant Ecology, 4, 292-301.

116. Weller S. G., Sakai A. K., Ranki A. E., Golonka A., Kutcher B. and Ashby K. E., 1998 Dioecy and the evolution of pollination systems in Schiedea and Alsinidendron (Caryophyllaceae: Alsinoideae) in the Hawaiian Islands, American Journal of Botany, 85, 1377-1388.

117. Wetson A. M., Zorb C., John E. A. and Flowers T. J., 2012 - High phenotypic plasticity of Suaeda maritima observed under hypoxic conditions in relation to its physiological basis, Annals of Botany, 109, 1027-1036.

118. Wheeler J. R., Rye B. L., Koch B. L. and Wilson A. J. G., 1992 - Western Australian Herbarium, Flora of the Kimberley Region, Western Australian Herbarium, Como, W. A., 1327

119. Yao-Wu Y., Mabberley D. J., Dorothy A. S. and Olmstead R. G., 2010 - Further disintegration and redefinition of Clerodendrum (Lamiaceae): Implications for the understanding of the evolution of an intriguing breeding strategy, Taxon, 59, 125-133.

120. Yeo A. R. and Flowers T. J., 1980 - Salt tolerance in the halophyte, Suaeda maritima L. Dum.: evaluation of the effect of salinity upon growth, Journal of Experimental Botany, 31, 11711183.

121. Zandonella P., 1977 - Morphologie pollinique et mode des pollinisation, Pollen et Spores, 19, 119-142.

122. Zhang Y. W., Yu Q., Zhao J. M. and Guo Y. H., 2009 - Differential effects of nectar robbing by the same bumble-bee species on three sympatric Corydalis species with varied mating systems, Annals of Botany, 104, 33-39.

123. Zimmerman M. and Cook S., 1985 - Pollinator foraging, experimental nectar-robbing and plant fitness in Impatiens capensis, American Midland Naturalist, 113, 84-91. 